Original article

\title{
Synthesis and biological evaluation of a new derivative of bevirimat that targets the Gag CA-SP1 cleavage site
}

\author{
Pascale Coric $^{\mathrm{a}}$, Serge Turcaud ${ }^{\mathrm{b}}$, Florence Souquet ${ }^{\mathrm{b}}$, Laurence Briant ${ }^{\mathrm{c}, \mathrm{d}}$, \\ Bernard Gay ${ }^{\mathrm{c}, \mathrm{d}}$, Jacques Royer ${ }^{\mathrm{b}}$, Nathalie Chazal ${ }^{\mathrm{c}, \mathrm{d}}$, Serge Bouaziz ${ }^{\mathrm{a}, *}$ \\ ${ }^{a}$ Université Paris Descartes, Sorbonne Paris Cité, Laboratoire de Cristallographie et RMN Biologiques, UMR 8015 CNRS, 4 av. de l'Observatoire, \\ Paris, France \\ ${ }^{\mathrm{b}}$ Université Paris Descartes, Sorbonne Paris Cité, SSMIP-UMR 8638 CNRS, 4 avenue de l'Observatoire, Paris, France \\ ' Université Montpellier 1, Centre d'études d'agents Pathogènes et Biotechnologies pour la Santé (CPBS), UMR 5236, CNRS, \\ 1919 route de Mende F-34293 Montpellier, France \\ ${ }^{\mathrm{d}}$ Université Montpellier 2, CPBS, F-34095 Montpellier, France
}

\section{A R T I C L E I N F O}

\section{Article history:}

Received 29 September 2012

Received in revised form

9 January 2013

Accepted 11 January 2013

Available online 19 January 2013

\section{Keywords:}

HIV maturation inhibitor

Betulinic acid

Bevirimat

DSB

CA-SP1 cleavage

\begin{abstract}
A B S T R A C T
Bevirimat (2), the first-in-class HIV-1 maturation inhibitor, shows a low efficacy due essentially to the natural polymorphism of its target, the CA-SP1 junction. Moreover, its low hydrosolubility makes it difficult to study its interaction with the CA-SP1 junction. We have synthesized new derivatives of bevirimat by adding different hydrophilic substituents at the $\mathrm{C}-28$ position to improve their hydrosolubility and perform the structural study of a complex by NMR. Synthesis of the new derivatives, the effect of substituents at the C-28 position and their hydrosolubility are discussed. The ability of these molecules to inhibit viral infection and their cytotoxicity is assessed. Compared to the well-known bevirimat (2), one of our compounds (16) shows a higher hydrosolubility associated with a 2.5 fold increase in activity, a higher selectivity index and a better antiviral profile. Moreover, for the first time a direct interaction between a derivative of bevirimat (16) and the domain CA-SP1-NC is shown by NMR. Information from this study should allow us to decipher the mechanism by which bevirimat inhibits HIV-1 maturation and how the natural polymorphism of the spacer peptide SP1 triggers resistance to inhibitors.
\end{abstract}

(c) 2013 Elsevier Masson SAS. All rights reserved.

\section{Introduction}

Most of the anti-HIV-1 drug inhibitors target the reverse transcriptase (RT) [1,2], the integrase (IN) [3,4] or the protease (PR) [1,5] and cause the emergence of multidrug-resistant HIV strains. Gag precursor (Pr55Gag) assembly and maturation are important steps of the HIV-1 replication and constitute attractive targets for the design of molecules competent to inhibit the retroviral cycle. Pr55Gag is necessary and sufficient for HIV-1 particle assembly and is cleaved during or after the assembly of the entire particle by PR in four mature proteins, matrix (MA), capsid (CA), nucleocapsid (NC),

Abbreviations: $\mathrm{Ac}_{2} \mathrm{O}$, acetic anhydride; DEPT135, Distortionless Enhancement by Polarization Transfer; DIEA, N,N-diisopropylethylamine; DMAP, 4-(dimethylamino) pyridine; DQF-COSY, double quantum filtered-correlation spectroscopy; HMBC, Heteronuclear Multiple Bond Correlation; HSQC, Heteronuclear Single Quantum Correlation; $n$ - $\mathrm{Bu}_{4} \mathrm{NF}$, tetrabutylammonium fluoride; PyBOP, (benzotriazol-1-yloxy) tripyrrolodinophosphonium hexafluorophosphate; $t$-BuMe ${ }_{2} \mathrm{SiOTf}_{\text {, tert-butyldime- }}$ thylsilyltrifluoromethanesulfonate; TOCSY, Total Correlation Spectroscopy.

* Corresponding author. Tel.: +3301537395 78; fax: +330143266918.

E-mail address: serge.bouaziz@parisdescartes.fr (S. Bouaziz). p6 and two extra spacer peptides, SP1 and SP2 [6,7]. The first cleavage occurs between SP1 and NC leading to the intermediate MA-CA-SP1, which is cleaved to MA and precursor CA-SP1 (p25). The cleavage of $\mathrm{p} 25$, critical for the proper formation of mature and infectious viral particles [8], occurs late in the virus life cycle to generate the mature CA (p24) and SP1.

The region surrounding the CA-SP1 junction plays an important role in the morphogenesis of the virion [9-14]. The mutation of the residues within the CA-SP1 junction results in the production of defective and noninfectious viral particles with aberrant cores $[12,15]$ demonstrating that the SP1 peptide is crucial both for HIV-1 assembly and maturation. Moreover, it has been shown that the presence of the SP1 domain at the C-terminus of CA allows Pr55Gag to multimerize [16]. Previous studies have shown that the CA-SP1 junction adopts an $\alpha$-helical conformation [17] confirmed recently by electron cryotomography studies of immature HIV-1 virions [18]. The ability of SP1 to undergo a concentrationdependent transition from a nearly unstructured conformation to an $\alpha$-helical one has suggested that SP1 behaves as a molecular switch to prime assembly of HIV-1 Pr55Gag in the immature lattice [19]. 
Derivatives of betulinic acid (BA, 1) (Fig. 1) retain antiviral properties against HIV-1 [20-22]. The 3-O-( $3^{\prime}, 3^{\prime}-$ dimethylsuccinyl)betulinic acid derivative, also referred to as DSB, PA-457 or bevirimat (2) (Fig. 1) exhibits an anti-HIV activity in acutely infected H9 lymphocytes with $\mathrm{EC}_{50}$ values greater than $3.5 \times 10^{-4} \mu \mathrm{M}[20,23]$ and blocks HIV-1 replication by interfering with the processing of CASP1 [15,24-26]. In vivo, bevirimat inhibits Pr55Gag assembly and VLP release in various cellular models, including mammalian cells as well as baculovirus-infected cells (Sf9) [27]. Recent results using cryo-electron tomography to examine the structures of HIV-1 viral particles isolated from DSB-treated cells suggest that DSB inhibits viral infectivity not only by blocking the CA-SP1 cleavage site but also by stabilizing the immature lattice [27]. Recently, it was shown that a molecule, PF-46396, structurally different from DSB had a similar mode of action and that these two molecules interact differently with the putative maturation inhibitor binding pocket [28].

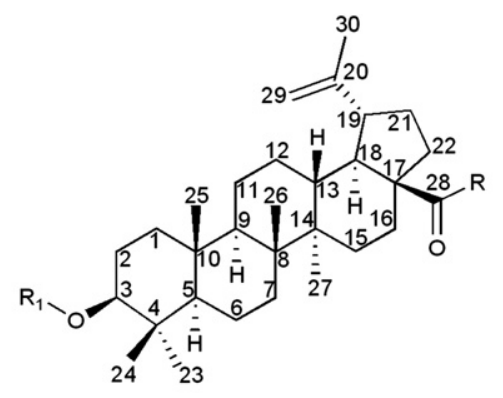

\section{R1}

$\mathbf{R}$

$\mathrm{H}$

$\mathrm{OH}$

$\mathrm{OH}$<smiles>CC(S)(CC(=O)O)C(=O)O</smiles>

-
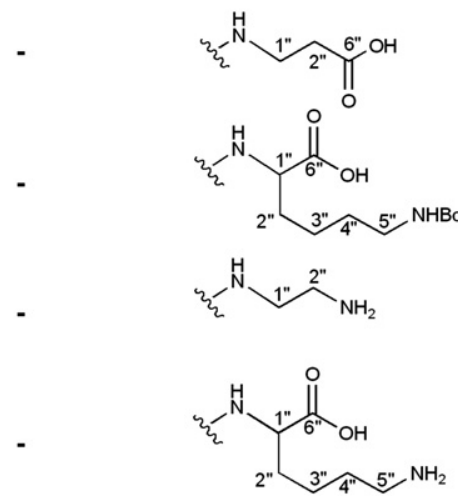

\section{Compound}

Betulinic Acid $(\mathrm{BA}, 1)$

Bevirimat (DSB, PA-457, 2)

12
Fig. 1. The structure of the betulinic acid (BA, 1), bevirimat (2) and derivatives containing a dimethyl group at the $\mathrm{C}-3$ position and various hydrophilic substituents at the $\mathrm{C}-28$ position. These molecules were synthesized to gain in hydro-

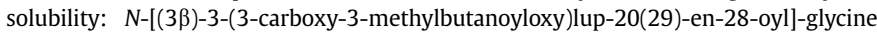
(12), $\quad N$-[(3 $\beta)-3-(3-c a r b o x y-3-m e t h y l b u t a n o y l o x y) l u p-20(29)-e n-28-o y l]-\beta$-alanine (13), $N^{6}$-[(1,1-dimethylethoxy)carbonyl, $N^{2}$-[(3ß)-3-(3-carboxy-3-methylbutanoyloxy)lup-20(29)-en-28-oyl]-L-lysine (15), 4-(\{28-[(2-aminoethyl)amino]-28-oxolup-20,29en-3 $\beta$-yl\}oxy)-2,2-dimethyl-4-oxobutanoic acid (16) and $N^{2}-[(3 \beta)-3-(3-c a r b o x y-3-$ methylbutanoyloxy)lup-20(29)-en-28-oyl]-L-lysine (17).
Derivatives of bevirimat having a side chain at the C-28 position, have been reported for their potent activity against HIV-1 replication and their interference with the processing of p25 [29-32]. Some of them block HIV-1 entry and constitute a new class of bi-functional inhibitors with the potential to block both entry and maturation. The introduction of basic substituents at the C-28 position of bevirimat results in compounds with high antiHIV activity [33]. Molecules derived from betulin that target the late stage of the replication have been proposed as anti-HIV agents $[34,35]$.

However, the nature of the interaction between Pr55Gag and bevirimat remains unclear and the characterization of those interactions may help to understand the mechanism underlying the inhibitory effect of bevirimat. Moreover, the design of new maturation inhibitors, derived from bevirimat, with improved efficiency against both assembly and maturation may also throw light on the mechanism. Such studies may also help to understand how the natural polymorphism of the CA-SP1 junction enables the virus to escape the effect of bevirimat. To address these queries and apprehend the mechanism by which bevirimat disrupts the maturation of the virion, we have initiated structural studies of the complex by NMR. Unfortunately, the structural study of both partners together was complicated by the lack of solubility of bevirimat in water as well as in the presence of organic solvents such as acetonitrile or trifluoroethanol. The $\mathrm{C}-3$ ester group within bevirimat is essential to interact with its target during HIV-1 maturation [36]. Consequently, novel bevirimat derivatives maintaining the dimethylsuccinyl group at the $\mathrm{C}-3$ position and various substituents at the $\mathrm{C}-28$ position, were synthesized to gain in hydrosolubility (Fig. 1 ): $N-[(3 \beta)-$ 3-(3-carboxy-3-methylbutanoyloxy)lup-20(29)-en-28-oyl]-glycine (12), $\quad N$-[(3 $\beta)$-3-(3-carboxy-3-methylbutanoyloxy)lup-20(29)-en28-oyl]- $\beta$-alanine (13), $\quad N^{6}$-[(1,1-dimethylethoxy)carbonyl, $\quad N^{2}$ [(3ß)-3-(3-carboxy-3-methylbutanoyloxy)-lup-20(29)-en-28-oyl]L-lysine (15), 4-(\{28-[(2-aminoethyl)amino]-28-oxolup-20,29-en$3 \beta$-yl\}oxy)-2,2-dimethyl-4-oxobutanoic acid (16) and $N^{2}-[(3 \beta)-3-$ (3-carboxy-3-methylbutanoyloxy)lup-20(29)-en-28-oyl]---lysine (17). Our goal was not to obtain new derivatives of bevirimat with higher activity against HIV replication but rather to get more hydrosoluble molecules with the same activity against HIV replication. Thus, we focused on the hydrosolubility of our compounds and various hydrophilic functions were added at the $\mathrm{C}-28$ position of bevirimat to make them amenable to NMR structural studies within a complex formed with peptides containing the CA-SP1 junction.

This paper describes the synthesis, the characterization by chemical analysis, NMR and Mass Spectroscopy (MS) of a new series of compounds. The polarity of these products was compared by HPLC analysis, their antiviral activity assessed and their $\mathrm{IC}_{50}$ value was determined. Their toxicity was controlled using models of mammalian cells infected with the NL4.3 HIV-1 laboratory strain and compared to bevirimat (2). One of our molecules (16) showed a better polarity evaluated by HPLC and an antiviral profile with a higher selectivity index. Moreover, for the first time, a direct interaction between compound $\mathbf{1 6}$ and the peptide CA-SP1-NC was proved by NMR. More recently, we showed that compound $\mathbf{1 6}$ was able to generate an aberrant assembly of VLP, resulting in nonenveloped, morula-like particles of $100 \mathrm{~nm}$ in diameter [37]. All together, these data constitute a first step in the understanding of the mechanism by which bevirimat inhibits HIV-1 assembly and maturation as proposed in a previous model [27,38]. Several patents have been filed describing derivatives of bevirimat at the C-28 position. None of them corresponds to the new molecules that we designed and synthesized except for one of them (WO 2006/ $053255 \mathrm{~A} 2$ ) that is quoted but has never been synthesized and its biological activity never tested against HIV-1. 


\section{Results}

\subsection{Chemistry}

In the last fifteen years, many BA derivatives have been synthesized with modifications at the C-3 hydroxyl [39], at the C-28 carboxylic acid [29,33-35]or at the C-19 isopropenyl groups along with their resulting functional properties [20,23,40,41]. Two distinct classes of BA derivatives exhibit different activities against HIV-1 according to the substitution. The BA derivatives in which the $\mathrm{C}-3$ hydroxyl group is acylated are efficient compounds against the cleavage of the CA-SP1 junction leading to maturation inhibition. Bevirimat (2) is the lead product of this derivative family (Fig. 1) developed by the pharmaceutical company Panacos $[39,40]$. We have synthesized this molecule, as previously described [20], with slight modifications [41]. The molecules with a C-3 hydroxyl group acylation have also been described to lead to assembly inhibition [41,42]. A second class of compounds produced by a modification of the C-28 carboxylic acid amide obtained by introducing a hydrophobic side chain was also studied. This class of BA derivatives, including the molecule named IC9564 was reported to inhibit HIV1 replication by blocking the viral entry step [21,22,32,43,44]. More recently, a comprehensive study of the structure-activity relationship of several BA derivatives has been achieved by using
3D-QSAR and docking methods and made it possible to propose new BA derivatives [45]. In the light of those results, the aim of our work was, starting from the bevirimat drug, to propose a series of more hydrosoluble molecules, by modifying the C-28 carboxylic acid function, while conserving intact the C-3 dimethylsuccinyl group required for HIV-1 maturation inhibition. Therefore, the side chain at the $\mathrm{C}-28$ position was modified by coupling different substituents. As an example, the free acid glycine conjugate of BA exhibits an increased hydrosolubility [48].

First, the C-3 hydroxyl group (1, Scheme 1 ) was protected by the acetyl group (3, Scheme 1$)$, then various substituents were introduced by peptide coupling with PyBOP and DIEA at the C-28 carboxylic acid. After the purification of the intermediates by flash chromatography (4-7, Scheme 1$)$, the saponification of the ester by a $4 \mathrm{M}$ sodium hydroxide solution was performed to furnish the compounds with free hydroxyl group at the C-3 position (8-11, Scheme 1). For compounds $\mathbf{8}, \mathbf{9}$ and $\mathbf{1 1}$ (Scheme 1) the saponification was accompanied by a non-classical tert-butyl ester cleavage of the coupled amino acid. The free hydroxyl derivatives (8-11, Scheme 1) reacted with the 2,2-dimethylsuccinic anhydride in pyridine, in the presence of DMAP, and provided a mixture of 3-

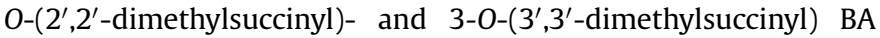
derivatives. The desired products $(\mathbf{1 2 - 1 5}$, Scheme 1$)$ were separated by flash chromatography. Data from the literature show that
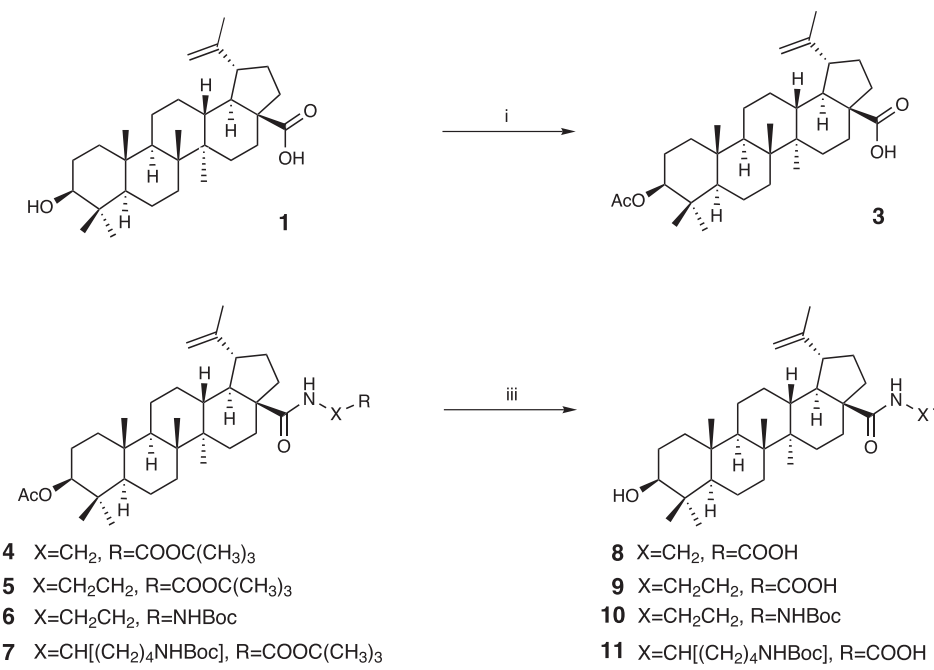

$4 \mathrm{X}=\mathrm{CH}_{2}, \mathrm{R}=\mathrm{COOC}\left(\mathrm{CH}_{3}\right)_{3}$

$5 \mathrm{X}=\mathrm{CH}_{2} \mathrm{CH}_{2}, \mathrm{R}=\mathrm{COOC}\left(\mathrm{CH}_{3}\right)_{3}$

$6 \mathrm{X}=\mathrm{CH}_{2} \mathrm{CH}_{2}, \mathrm{R}=\mathrm{NHBOC}$

$7 \mathrm{X}=\mathrm{CH}\left[\left(\mathrm{CH}_{2}\right)_{4} \mathrm{NHBoc}\right], \mathrm{R}=\mathrm{COOC}\left(\mathrm{CH}_{3}\right)_{3}$

$11 \mathrm{X}=\mathrm{CH}\left[\left(\mathrm{CH}_{2}\right)_{4} \mathrm{NHBoc}\right], \mathrm{R}=\mathrm{COOH}$

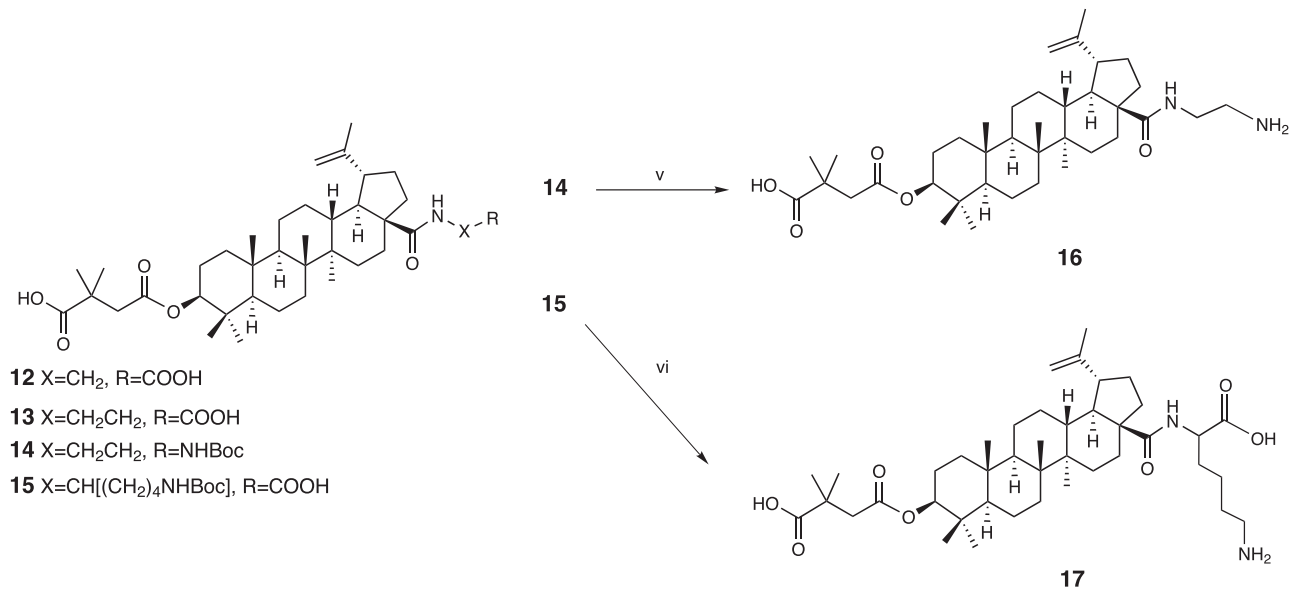

${ }^{a}$ Reagents and conditions: (i) $\mathrm{Ac}_{2} \mathrm{O}$, pyridine; (ii) PyBop, DIEA, $\mathrm{NH}_{2}-\mathrm{X}-\mathrm{R}, \mathrm{rt}, 72 \mathrm{~h}$; (iii) $\mathrm{NaOH} 4 \mathrm{M}, \mathrm{THF} / \mathrm{MeOH}$, rt, $12 \mathrm{~h}$; (iv) anhydride, DMAP, pyridine, reflux, $18 \mathrm{~h}$; (v) 2,6-lutidine, $t$ - $\mathrm{BuMe}_{2} \mathrm{SiOTf}_{2} \mathrm{CH}_{2} \mathrm{Cl}_{2}, 30 \mathrm{mn}, n$-Bu $\mathrm{BF}_{4}$, THF, rt, $1 \mathrm{~h}$; (vi) $\mathrm{HCl} 6 \mathrm{M}, \mathrm{THF}, \mathrm{rt}, 1 \mathrm{~h}$

Scheme 1. Synthesis of the derivatives of bevirimat. 
the $3-O-\left(3^{\prime}, 3^{\prime}\right.$-dimethylsuccinyl $)$ betulinic acid was a more potent anti-HIV-1 inhibitor than the 3-O-( $2^{\prime}, 2^{\prime}$-dimethylsuccinyl $)$ betulinic acid [20].

The $N$-Boc protection of product 14 (Scheme 1) was first removed with tert-butyldimethylsilyltrifluoromethanesulfonate in the presence of 2,6-lutidine to produce tert-butyldimethylsilyl carbamates [46]. The removal of the $N$-tert-butyldimethylsilyloxycarbonyl group was then achieved by treatment with $n$ - $\mathrm{Bu}_{4} \mathrm{NF}$ in THF leading to compound 16. The $\mathrm{N}$-Boc protection of product 15 (Scheme 1) was cleaved with $6 \mathrm{M} \mathrm{HCl}$ in THF and compound 17 was obtained after purification by flash chromatography.

\subsection{Analysis of the polarity of the compounds by HPLC}

As substitutions at the $\mathrm{C} 28$ position were performed to increase the polarity of bevirimat and subsequently its hydrosolubility, while keeping intact the function at the $\mathrm{C}-3$ position, we assessed their hydrosolubility by HPLC after purification. The compounds were analyzed with an isocratic HPLC mode using $\mathrm{MeOH}(90 \%)$ in water as solvent and a C18 column. In these conditions it was possible to correlate the polarity of the compounds with their retention time (Fig. 2). As an example, a glycine residue introduced at the C28 position in bevirimat (retention time: $17.890 \mathrm{~min}$ ) divided by two the retention time in compound $\mathbf{1 2}$ (retention time: $8.352 \mathrm{~min}$ ). These results are in keeping with those obtained previously on a derivative of the betulinic acid [47]. The most interesting compounds were found to be $\mathbf{1 6}$ and $\mathbf{1 7}$ with respectively an ethylenediamine and a lysine group as substituent at the $\mathrm{C} 28$ position and a retention time of $3.428 \mathrm{~min}$ and $2.295 \mathrm{~min}$ respectively determined by HPLC analysis. The compounds were classified according to their retention time (or polarity) from the most hydrophilic compound to the least hydrophilic one $(\mathbf{1 7}>\mathbf{1 6}>\mathbf{1 2}>\mathbf{1 3}>\mathbf{1}>\mathbf{2})$.

\section{3. $N M R$}

Our compounds were characterized by High Resolution Mass Spectroscopy (HRMS) and by NMR. The complete assignment of the ${ }^{1} \mathrm{H}$ (Table 1 ) and ${ }^{13} \mathrm{C}$ (Table 2 ) resonances was achieved by standard 1D and 2D NMR experiments, the IUPAC convention was used to number the carbon atoms. ${ }^{1} \mathrm{H}-{ }^{1} \mathrm{H}$ COSY (COrrelations SpectroscopY), TOCSY (TOtal Correlation SpectroscopY), 2D $\left({ }^{1} \mathrm{H}-{ }^{13} \mathrm{C}\right)-\mathrm{HSQC}$ (Heteronuclear Single Quantum Correlation) and 2D $\left({ }^{1} \mathrm{H}-{ }^{13} \mathrm{C}\right)-$ HMBC (Heteronuclear Multi Bond Correlation). The ${ }^{13} \mathrm{C}$ spectra of the six products $(\mathbf{2}, \mathbf{1 2}, \mathbf{1 3}, \mathbf{1 5}, \mathbf{1 6}$ and $\mathbf{1 7})$ revealed 36 to 48 carbon signals out of which 6 were assigned to the C-3 esterification ( $1^{\prime}$ to $4^{\prime}$, two $5^{\prime}$ methyl), 6 to the C-28 amide modifications ( $1^{\prime \prime}$ to $6^{\prime \prime}$ ) and 30 to the triterpenoid skeleton (Figures S1 to S5 in supplementary data).

Significant variations were observed when comparing the carbon chemical shifts of bevirimat and its derivatives with those reported for the BA $[48,49]$, mainly for the carbons C-2 $(\Delta \delta=-4 \mathrm{ppm}), \mathrm{C}-3(\Delta \delta=+3 \mathrm{ppm})$ and $\mathrm{C}-4(\Delta \delta=-1 \mathrm{ppm})$ resulting from $\mathrm{C}-3$ esterification and $\mathrm{C}-16(\Delta \delta=+0.4$ to $+1 \mathrm{ppm})$, $\mathrm{C}-18(\Delta \delta=+0.3$ to $+1 \mathrm{ppm}), \mathrm{C}-20(\Delta \delta=+0.5$ to $+1 \mathrm{ppm}), \mathrm{C}-22$ $(\Delta \delta=+0.4$ to $+1.5 \mathrm{ppm}), \mathrm{C}-24(\Delta \delta=+1 \mathrm{ppm})$ and $\mathrm{C}-28$ $(\Delta \delta=-1.6 \mathrm{ppm}$ to +0.5$)$ consecutive to the C-28 amide modification. Moreover, the carbon signal of $\mathrm{C}-24$ was more perturbed than that of $\mathrm{C}-23$ because it is located above the plane of the first ring $A$, as is the hydroxyl group at the $C-3$ position. All together, these data support that the configuration of $\mathrm{C}-3$ was well conserved during the synthesis.

The opening of the 2,2-dimethylsuccinic anhydride during the C-3 esterification synthesis leads to the formation of two compounds, which can be differentiated, on the $2 \mathrm{D}\left({ }^{1} \mathrm{H}-{ }^{13} \mathrm{C}\right)-\mathrm{HMBC}$ experiment (data not shown). We observed that the $\mathrm{C}-4^{\prime}$ carbon
A

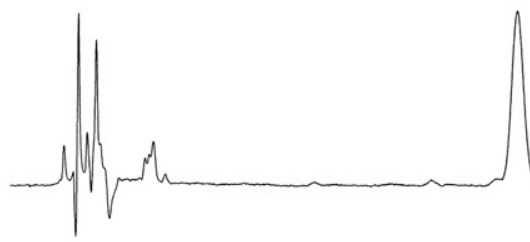

17.890

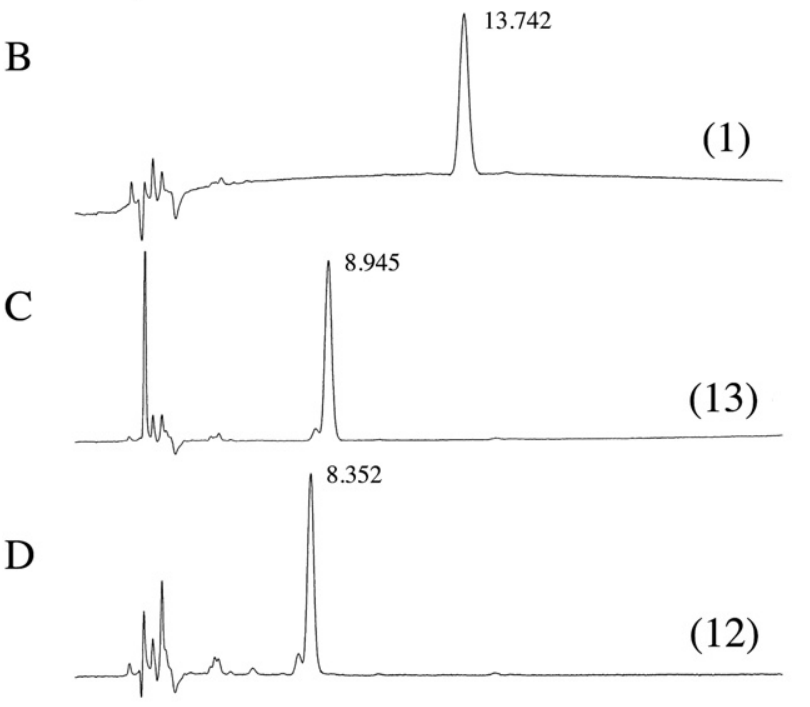

$\mathrm{E}$

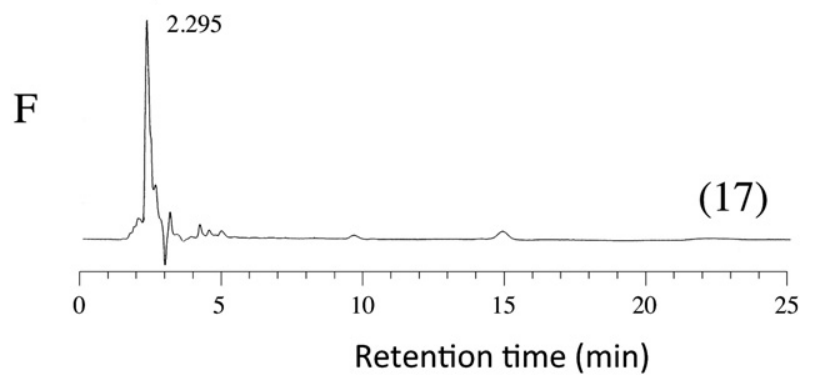

Fig. 2. The evaluation of the retention times of the different compounds $(\mathbf{1}, \mathbf{2}, \mathbf{1 2}, \mathbf{1 3}, \mathbf{1 6}$ and 17) by HPLC analysis conducted on a Shimadzu LC-10ADvp with a Nucleodur $4.6 \mathrm{~mm} \times 250 \mathrm{~mm} \mathrm{C18} \mathrm{HTec} 5 \mu \mathrm{m}$ column and a Shimadzu SPD-M10Avp detector at $210 \mathrm{~nm}$ wavelength. The solvent system used was MeOH(0.1\%TFA):water(0.1\% TFA) $=90: 10$ with an isocratic HPLC mode. In these conditions it was possible to compare the water solubility of the compounds and classify them according to their retention time from the most hydrophilic compound to the least hydrophilic one $17>16>12>13>1>2$. Compound 15 has not been tested by HPLC since it corresponds to compound $\mathbf{1 7}$ with a $\mathrm{N}$-Boc protection of the $\mathrm{HN} \varepsilon$ of lysine. It is then thought to be less hydrosoluble than $\mathbf{1 7}$.

signal strongly correlates with the $\mathrm{H}-5^{\prime}$ proton signal for the 3-O(3',3'-dimethylsuccinyl) betulinic acid derivatives while the same $\mathrm{H}-5^{\prime}$ proton strongly correlates with the $\mathrm{C}-1^{\prime}$ carbon signal for the $2-O-\left(2^{\prime}, 2^{\prime}\right.$-dimethylsuccinyl $)$ betulinic acid derivatives. Additionally, the $2 \mathrm{D}\left({ }^{1} \mathrm{H}-{ }^{13} \mathrm{C}\right)-\mathrm{HMBC}$ spectrum shows that the $\mathrm{H}-3$ proton signal correlates with the $\mathrm{C}-1^{\prime}$ carbon signal and not with the $\mathrm{C}-4^{\prime}$ one. These data validate the correct incorporation of the chain at the $\mathrm{C}-3$ position of the purified compounds. The correlations between the $\mathrm{C}-28$ carbon signal and the $\mathrm{NH}$ and $\mathrm{H}-1^{\prime \prime}$ proton signals for the five bevirimat derivatives prove the correct formation of the amide. 
Table 1

${ }^{1} \mathrm{H}$ NMR spectral data for $2, \mathbf{1 2}, \mathbf{1 3}, \mathbf{1 5}, \mathbf{1 6}$ in pyridine- $\mathrm{d}_{5}$ and 17 in methanol- $\mathrm{d}_{4} \cdot$ o, overlapped signals.

\begin{tabular}{|c|c|c|c|c|c|c|}
\hline & 2 & 12 & 13 & 15 & 16 & 17 \\
\hline & $\delta_{\mathrm{H}}$ & $\delta_{\mathrm{H}}$ & $\delta_{\mathrm{H}}$ & $\delta_{\mathrm{H}}$ & $\delta_{\mathrm{H}}$ & $\delta_{\mathrm{H}}$ \\
\hline 1 & $0.911 .56(0)$ & $0.891 .52(0)$ & $0.911 .58(0)$ & 0.91 .59 (o) & $0.861 .54(0)$ & $0.991 .72(0)$ \\
\hline 2 & $1.661 .8(0)$ & $1.671 .77(0)$ & $1.71 .82(0)$ & $1.71 .78(\mathrm{o})$ & $1.671 .77(0)$ & $1.61 .68(0)$ \\
\hline \multirow[t]{2}{*}{3} & $4.76(d)(0)$ & $4.77(\mathrm{~d})$ & $4.78(0)$ & $4.78(\mathrm{dd})$ & $4.77(\mathrm{o}) \mathrm{d}$ & $4.44(\mathrm{dd})$ \\
\hline & $J=5.5 \mathrm{~Hz}$ & $J=5 \mathrm{~Hz}$ & & $J=5 \mathrm{~Hz}, 11.5 \mathrm{~Hz}$ & & $J=5 \mathrm{~Hz}, 10 \mathrm{~Hz}$ \\
\hline 4 & - & - & - & - & - & - \\
\hline 5 & $\begin{array}{l}0.77(\mathrm{~d}) \\
J=11 \mathrm{~Hz}\end{array}$ & $0.77(0)$ & $0.74(0)$ & $0.82(0)$ & $0.77(0)$ & $0.82(0)$ \\
\hline 6 & $1.42(0)$ & $1.31 .4(\mathrm{o})$ & $1.31 .4(\mathrm{o})$ & $1.361 .46(0)$ & $1.31 .4(\mathrm{o})$ & $1.441 .52(\mathrm{o})$ \\
\hline 7 & $1.32(0)$ & $1.37(0)$ & $1.33(0)$ & $1.44(0)$ & $1.30(\mathrm{o})$ & $1.381 .45(\mathrm{o})$ \\
\hline 8 & - & - & - & - & - & - \\
\hline 9 & $1.29(0)$ & $1.3(\mathrm{o})$ & $1.3(0)$ & $1.30(0)$ & $1.28(0)$ & $1.36(0)$ \\
\hline 10 & - & - & - & - & - & - \\
\hline 11 & $1.21 .3(0)$ & $1.151 .3(0)$ & $1.171 .31(\mathrm{o})$ & $1.151 .33(0)$ & $1.131 .3(0)$ & $1.261 .43(0)$ \\
\hline 12 & $1.151 .94(0)$ & $\begin{array}{l}1.15(\mathrm{o}) \\
1.93(\mathrm{~m})\end{array}$ & $\begin{array}{l}1.16(\mathrm{o}) \\
1.96(\mathrm{~m})\end{array}$ & $\begin{array}{l}1.15 \\
1.95(0)\end{array}$ & 1.12(o) $1.92(\mathrm{~m})$ & $1.041 .7(0)$ \\
\hline 13 & $2.73(\mathrm{~m})$ & $3.08(\mathrm{~m})$ & $3.04(\mathrm{~m})$ & $3.07(\mathrm{~m})$ & $3.03(\mathrm{~m})$ & $2.53(\mathrm{o})$ \\
\hline 14 & - & - & - & - & - & - \\
\hline 15 & $1.221 .84(\mathrm{o})$ & $1.262 .03(\mathrm{~m})$ & $1.21 .85(\mathrm{o})$ & $1.321 .89(0)$ & $1.171 .7(\mathrm{o})$ & $1.181 .49(\mathrm{o})$ \\
\hline 16 & $1.55(\mathrm{o}) 2.63(\mathrm{~m})$ & 1.67(o) 2.59(m) & $\begin{array}{l}1.58(\mathrm{o}) 2.44(\mathrm{~d}) \\
J=13 \mathrm{~Hz}\end{array}$ & $1.67(\mathrm{o}) 2.58(\mathrm{~m})$ & $\begin{array}{l}1.64(\mathrm{o}) 2.67(\mathrm{~d}) \\
J=12 \mathrm{~Hz}\end{array}$ & $1.56(\mathrm{o}) 2.17(\mathrm{~m})$ \\
\hline 17 & - & - & - & - & - & - \\
\hline 18 & $1.75(\mathrm{o})$ & $1.74(\mathrm{o})$ & $1.7(0)$ & $1.73(0)$ & $1.7(\mathrm{o})$ & $1.64(0)$ \\
\hline 19 & $3.55(\mathrm{~m})$ & $3.66(\mathrm{~m})$ & $3.64(\mathrm{~m})$ & $3.64(\mathrm{~m})$ & $3.61(\mathrm{~m})$ & $3.06(\mathrm{~m})$ \\
\hline 20 & - & - & - & - & - & - \\
\hline 21 & $1.562 .26(\mathrm{o})$ & $1.542 .38(\mathrm{o})$ & $1.5(\mathrm{o}) 2.24(\mathrm{~m})$ & $1.53(\mathrm{o}) 2.34(\mathrm{~m})$ & $1.482 .14(\mathrm{~m})$ & $1.351 .9(0)$ \\
\hline 22 & $1.562 .25(\mathrm{o})$ & $1.592 .39(0)$ & $1.52(\mathrm{o}) 2.14(\mathrm{~m})$ & $1.54(\mathrm{o}) 2.43(\mathrm{~m})$ & $1.552 .25(\mathrm{~m})$ & $1.471 .93(\mathrm{o})$ \\
\hline 23 & $0.97(s)$ & $0.96(s)$ & $0.97(\mathrm{~s})$ & $0.97(\mathrm{~s})$ & $0.97(\mathrm{~s})$ & $0.87(\mathrm{~s})$ \\
\hline 24 & $0.92(\mathrm{~s})$ & $0.92(\mathrm{~s})$ & $0.94(s)$ & $0.96(\mathrm{~s})$ & $0.93(\mathrm{~s})$ & $0.85(\mathrm{~s})$ \\
\hline 25 & $0.73(\mathrm{~s})$ & $0.73(\mathrm{~s})$ & $0.74(\mathrm{~s})$ & $0.76(\mathrm{~s})$ & $0.75(\mathrm{~s})$ & $0.92(\mathrm{~s})$ \\
\hline 26 & $1.02(\mathrm{~s})$ & $1.12(\mathrm{~s})$ & $1.08(\mathrm{~s})$ & $1.09(\mathrm{~s})$ & $1.03(0)$ & $0.96(\mathrm{~s})$ \\
\hline 27 & $1.05(\mathrm{~s})$ & $1.06(\mathrm{~s})$ & $1.04(\mathrm{~s})$ & $1.08(\mathrm{~s})$ & $1.03(0)$ & $1.01(\mathrm{~s})$ \\
\hline 28 & - & - & - & - & - & - \\
\hline 29 & $4.78(\mathrm{~s}) 4.95(\mathrm{~s})$ & $4.75(\mathrm{~s}) 4.96(\mathrm{~s})$ & $4.77(\mathrm{~s}) 4.94(\mathrm{o})$ & $4.77(\mathrm{~s}) 4.92(\mathrm{~s})$ & $4.75(\mathrm{~s}) 4.93(\mathrm{~s})$ & $4.57(\mathrm{~s}) 4.7(\mathrm{~s})$ \\
\hline 30 & $1.78(\mathrm{~s})$ & $1.78(\mathrm{~s})$ & $1.81(\mathrm{~s})$ & $1.78(\mathrm{~s})$ & $1.77(\mathrm{~s})$ & $1.7(\mathrm{~s})$ \\
\hline $\mathbf{1}^{\prime}$ & - & - & - & - & - & - \\
\hline \multirow[t]{2}{*}{$2^{\prime}$} & $2.892 .97(2 \mathrm{~d})$ & $2.912 .95(2 \mathrm{~d})$ & $2.943 .00(2 \mathrm{~d})(\mathrm{o})$ & $2.902 .98(2 \mathrm{~d})$ & $2.92 .96(2 d)$ & $2.552 .62(2 d)$ \\
\hline & $J=15 \mathrm{~Hz}$ & $J=15.5 \mathrm{~Hz}$ & $J=15.5 \mathrm{~Hz}$ & $J=15.5 \mathrm{~Hz}$ & $J=15.5 \mathrm{~Hz}$ & $J=15.5 \mathrm{~Hz}$ \\
\hline $\mathbf{3}^{\prime}$ & - & - & - & - & - & - \\
\hline $4^{\prime}$ & - & - & - & - & - & - \\
\hline $\mathbf{5}^{\prime}$ & $1.55(0)$ & $1.55(0)$ & $1.55(0)$ & $1.55(0)$ & $1.55(0)$ & $1.25(\mathrm{o})$ \\
\hline $\mathbf{1}^{\prime \prime}$ & & $\begin{array}{l}4.444 .51(\mathrm{dd}) \\
J=6 \mathrm{~Hz}, 17.5 \mathrm{~Hz}\end{array}$ & $3.884 .00(\mathrm{~m})$ & $5.17(\mathrm{~m})$ & $3.873 .81(\mathrm{~m})$ & $4.3(\mathrm{~m})$ \\
\hline $2^{\prime \prime}$ & & & $3.00(\mathrm{mo})$ & $2.062 .31(\mathrm{~m})$ & $3.28(\mathrm{~m})$ & $1.751 .89(\mathrm{~m})$ \\
\hline 3" & & & & $1.80(0)$ & & $1.46(0)$ \\
\hline 4" & & & & $1.74(\mathrm{o}) 1.83$ & & 1.7 \\
\hline 5" & & & & $3.43(\mathrm{~m})$ & & $2.9(\mathrm{t}) \mathrm{J}=8 \mathrm{~Hz}$ \\
\hline 6" & & - & - & - & & - \\
\hline NH & & $8.76(\mathrm{t}) J=5.5 \mathrm{~Hz}$ & $8.33(\mathrm{t}) \mathrm{J}=5.5 \mathrm{~Hz}$ & $8.27(\mathrm{~d}) \mathrm{J}=8 \mathrm{~Hz}$ & $8.74(0)$ & 7.1 \\
\hline
\end{tabular}

Several remarks regarding the proton chemical shifts (Fig. 3) can be made. The most important variation concerns the $\mathrm{H}-3 \alpha$ that is less shielded $(+1.3 \mathrm{ppm})$ after the esterification of the $\beta$-hydroxyl group. The chemical shifts of the $\mathrm{H}-1$ protons ( $\alpha$ and $\beta$ ), H-6 $\beta, \mathrm{H}-9$, $3 \mathrm{H}-23$ and the $3 \mathrm{H}-25$ differ by $0.1-0.2 \mathrm{ppm}$. The supplementary changes resulting from the $\mathrm{C}-28$ amide modifications concern the $\mathrm{H}-13$ proton $(+0.3 \mathrm{ppm})$.

The most active compound (16) was tested by NMR in interaction with a wild type CA-SP1-NC peptide containing 48 amino acids [17] and derived from the HIV-1 Pr55Gag sequence (Fig. 4A). NOESY experiments were performed on the peptide in the presence or not of compound $\mathbf{1 6}$ and perturbation of the chemical shifts of the junction CA-SP1-NC has been analyzed, demonstrating that an interaction takes place between compound 16 and the wild type junction (Fig. 4B). The amino acids involved in the interaction with compound $\mathbf{1 6}$ were identified within SP1-(A366, M367, Q369, V370, N372 and I376) and in the NC (M378). Some amino acids showed their chemical shifts perturbed after the addition of compound $\mathbf{1 6}$ but they were located in the unstructured $\mathrm{N}$ - and the C-terminal extremities of the peptide and were very sensitive to the solvent conditions. The perturbation of the chemical shifts of the wild type junction is represented as a histogram (Fig. 4C).

\subsection{Bio assays}

Novel bevirimat derivatives with higher solubility, containing the dimethyl group at the $\mathrm{C}-3$ position and various modifications at the C-28 amide position were tested for their capacity to inhibit HIV-1 assembly and/or maturation and consequences on viral infectivity were determined. To this end, viruses produced by transfection of the HIV-1 pNL-4-3 molecular clones in 293T cells maintained in the presence of newly synthesized compounds $\mathbf{1 2}$, 13, 15, 16 and 17 were analyzed for their capacity to infect MAGIC$5 \mathrm{~B}$ cells in parallel with BA (1) and bevirimat (2). All compounds displayed an $\mathrm{IC}_{50}$ value lower than that of $\mathbf{B A}$, with compound $\mathbf{1 6}$ being more efficient than bevirimat at inhibiting HIV-1 infectivity. The bioassay data are summarized in Table 3. 
Table 2

${ }^{13} \mathrm{C}$ spectral data for $2,12,13,15,16$ in pyridine- $\mathrm{d}_{5}$ and 17 in methanol- $\mathrm{d}_{4}$.

\begin{tabular}{|c|c|c|c|c|c|c|}
\hline & 2 & 12 & 13 & 15 & 16 & 17 \\
\hline & $\delta_{\mathrm{C}}$ & $\delta_{\mathrm{C}}$ & $\delta_{\mathrm{C}}$ & $\delta_{\mathrm{C}}$ & $\delta_{\mathrm{C}}$ & $\delta_{\mathrm{C}}$ \\
\hline 1 & 39.0 & 39.0 & 39.0 & 39.0 & 39.1 & 39.8 \\
\hline 2 & 24.6 & 24.6 & 24.6 & 24.6 & 24.6 & 24.8 \\
\hline 3 & 81.3 & 81.4 & 81.4 & 81.4 & 81.3 & 82.8 \\
\hline 4 & 38.5 & 38.5 & 38.5 & 38.5 & 38.5 & 39 \\
\hline 5 & 56.1 & 56.0 & 56.1 & 56.1 & 56.1 & 57 \\
\hline 6 & 18.85 & 18.9 & 18.9 & 19.0 & 19.0 & 19.4 \\
\hline 7 & 35.0 & 35.0 & 35.0 & 35.15 & 35.0 & 35.7 \\
\hline 8 & 41.45 & 41.6 & 41.6 & 41.6 & 41.5 & 42.2 \\
\hline 9 & 51.05 & 51.2 & 51.2 & 51.2 & 51.3 & 52.1 \\
\hline 10 & 37.7 & 37.7 & 37.75 & 37.75 & 37.7 & 38.4 \\
\hline 11 & 21.6 & 21.6 & 21.7 & 21.7 & 21.6 & 22.3 \\
\hline 12 & 26.4 & 26.6 & 26.6 & 26.6 & 26.5 & 27.2 \\
\hline 13 & 39.0 & 38.1 & 38.2 & 38.1 & 38.1 & 39.2 \\
\hline 14 & 43.25 & 43.2 & 43.2 & 43.2 & 43.15 & 43.7 \\
\hline 15 & 30.7 & 30.3 & 30.3 & 30.3 & 30.3 & 30.9 \\
\hline 16 & 33.3 & 34.0 & 34.0 & 34.2 & 34.0 & 34.4 \\
\hline 17 & 57.0 & 56.4 & 56.3 & 56.5 & 56.5 & 57.4 \\
\hline 18 & 50.1 & 51.0 & 51.1 & 51.1 & 51.2 & 51.4 \\
\hline 19 & 48.2 & 47.7 & 47.7 & 47.7 & 47.7 & 48.3 \\
\hline 20 & 151.8 & 152.2 & 152.2 & 152.2 & 152.2 & 152.4 \\
\hline 21 & 31.6 & 31.8 & 31.8 & 31.9 & 31.8 & 32.1 \\
\hline 22 & 38.0 & 39.1 & 39.0 & 38.8 & 39.0 & 39.3 \\
\hline 23 & 28.5 & 28.5 & 28.6 & 28.6 & 28.5 & 28.7 \\
\hline 24 & 17.35 & 17.3 & 17.4 & 17.4 & 17.4 & 17.2 \\
\hline 25 & 16.65 & 16.7 & 16.7 & 16.7 & 16.75 & 17.0 \\
\hline 26 & 16.8 & 17.0 & 16.9 & 17.0 & 16.9 & 17.1 \\
\hline 27 & 15.3 & 15.3 & 15.2 & 15.3 & 15.2 & 15.2 \\
\hline 28 & 179.3 & 177.9 & 177.2 & 177.7 & 177.7 & 178.9 \\
\hline 29 & 110.5 & 110.3 & 110.2 & 110.2 & 110.2 & 110.2 \\
\hline 30 & 19.9 & 20.0 & 20.0 & 20.0 & 20.0 & 19.8 \\
\hline $\mathbf{1}^{\prime}$ & 172 & 172.1 & 172.0 & 172.1 & 172.1 & 173.1 \\
\hline $\mathbf{2}^{\prime}$ & 45.7 & 45.7 & 45.7 & 45.7 & 45.7 & 45.8 \\
\hline $3^{\prime}$ & 41.3 & 41.3 & 41.3 & 41.3 & 41.4 & 41.5 \\
\hline $4^{\prime}$ & 179.8 & 179.8 & 179.8 & 179.8 & 179.9 & 180.8 \\
\hline $\mathbf{5}^{\prime}$ & 26.7 & 26.7 & 26.7 & 26.4 & 26.7 & 26.2 \\
\hline $\mathbf{1}^{\prime \prime}$ & & 42.4 & 36.7 & 53.0 & 41.05 & 54.0 \\
\hline $2^{\prime \prime}$ & & & 35.7 & 32.4 & 42.2 & 32.7 \\
\hline $3^{\prime \prime}$ & & & & 24.5 & & 24.05 \\
\hline $4^{\prime \prime}$ & & & & 30.6 & & 28.2 \\
\hline $\mathbf{5}^{\prime \prime}$ & & & & 41.4 & & 40.7 \\
\hline $6^{\prime \prime}$ & & 174.0 & 175.4 & 176.6 & & 177.3 \\
\hline
\end{tabular}

To further elucidate the mechanism of action of these compounds, viral samples used for infection assays were subjected to biochemical characterization (Fig. 5). The analysis of the conversion of uncleaved p25 (CA-SP1) to mature p24 (CA) revealed that compounds 2, 12, 13, 15 and 16 partially inhibit the CA-SP1 cleavage while compounds 1 and $\mathbf{1 7}$ do not. However, this biochemical approach is dependent on the threshold of sensitivity of Western blot and we can not exclude that the cleavage is inhibited for few molecules of CA-SP1.

To determine whether defect in $\mathrm{p} 25$ to $\mathrm{p} 24$ process induced by $\mathbf{1 , 2}$, 12,13, 15, 16 and 17 affected virus morphology, an analysis by EM was performed. In the absence of compounds, cells transfected with pNL-4-3 produced virus particles with the classical mature morphology characterized by the presence of condensed, conical cores (Fig. 6A). In contrast, viruses from cells treated with 2,12,13,15 and 16 displayed different phenotype with various distribution from aberrant, spherical and acentric core to aberrant immature virions (Chazal, $\mathrm{N}$ et al., in preparation) (Fig. 6C-G). Compounds $\mathbf{1}$ and $\mathbf{1 7}$ had almost no capacity to inhibit viral maturation. Taken together, these results indicate that $2,12,13,15$ and 16 positively block proper virion maturation.

\section{Discussion}

Very recently different modifications at the $\mathrm{C}-3$ position of antiHIV triterpene-derived agents have been proposed and showed that the C-3 dimethyl substitution of the succinyl side chain as well as the carboxylic acid, were necessary for antiviral activity [50-52]. Although it is efficient in ex vivo bio assays, the use of bevirimat (2) as an anti-HIV drug is hindered by its low efficacy due to the wide natural polymorphism of the spacer peptide SP1 [53-58]. Moreover, bevirimat (2) was shown to have a low solubility in physiological solvents as well as in organic solvent mixtures, preventing any structural study by NMR of a complex with the CA-SP1-NC domain previously characterized as an amphipathic helix [17].

We optimized the synthesis of triterpene derivatives by adding different hydrophilic substituents at the $C-28$ position $(\mathbf{1 2}, \mathbf{1 3}, \mathbf{1 5}, 16$ and 17). The new molecules showing a higher polarity according to their retention time evaluated by HPLC, were characterized by NMR and by HRMS, they were tested for their capacity to inhibit viral infectivity and their cytotoxicity was evaluated (Table 3). We showed that the essential maturation inhibitory activity of our molecules, due to the dimethylsuccinyl group at the $\mathrm{C}-3$ position, was conserved for all the molecules and therefore our compounds remained fully active against maturation and replication.

Moreover, the most active compound (16) was shown to interact with the junction CA-SP1-NC by chemical shift perturbation NMR experiments (Fig. 4B). The amino acids involved in this interaction were identified in the domain SP1 (A366, M367, Q369, V370, N372, I376) and in NC (M378). Our data confirm the results obtained recently with photoaffinity analogs of bevirimat that were found to crosslink to sequences overlapping the CA-SP1 junction and are consistent with previous biochemical data on the effect of bevirimat on Pr55 Gag processing [59]. Thus, introduction of a constituent containing an amino group at the $\mathrm{C}-28$ position of bevirimat made it possible to demonstrate by NMR for the first time a direct interaction between a maturation inhibitor and its target within the CA-SP1-NC junction. This NMR study was impossible to realize with bevirimat because of its weak solubility in water.

The newly synthesized bevirimat derivatives were evaluated for their capacity to inhibit HIV-1 replication by blocking the protease (PR)-mediated cleavage at the CA-SP1 junction. Only derivative $\mathbf{1 7}$ showed a moderate anti-HIV-1 activity with a selectivity index (SI) of 11 and an $\mathrm{IC}_{50}$ of $4.33 \mu \mathrm{M}$. However, we found that all compounds 12, 13, 15 and 16 exhibited a good anti-HIV-1 efficacy with an $\mathrm{IC}_{50}$ values of $0.160 \mu \mathrm{M}, 0.118 \mu \mathrm{M}, 0.170 \mu \mathrm{M}$ and $0.016 \mu \mathrm{M}$ and a SI of 309, 411, 199 and 2118 respectively. These results should be compared to those obtained in a very recent publication by Qian et al. [31] in which a product with an $\mathrm{IC}_{50}$ of $0.0059 \mu \mathrm{M}$ was studied.

To elucidate the mechanism of action of our series of compounds, HIV- $1_{\text {NL4.3 }}$ particles produced by transfection of $293 \mathrm{~T}$ cells maintained in the presence of the newly synthesized molecules were subjected to characterization. Biochemical analysis of cell free viral particles revealed that, derivatives 12, 15 and $\mathbf{1 6}$ function as maturation inhibitors and partially inhibit the conversion of p25 (CA-SP1) to p24 (CA) as previously reported for BA and bevirimat. These compounds result in a defective Pr55Gag processing and to the production of morphologically abnormal and noninfectious particles.

Among all tested molecules, compound 16, displayed the most potent anti-HIV-1 activity. It is important to note that this molecule, unlike other derivatives designed in this work, is the only one that does not come from the condensation with an amino acid at the C28 position. It seems that the presence of the carboxylic group, introduced by the condensation of an amino acid at the C-28 position, decreases the activity of our compounds (12 and 13), compared to the introduction of an amino group (16). Moreover the distance between the triterpenic skeleton and the carboxylic function may modulate this activity as shown by the comparison of the results obtained with compounds 2, 12 and 13 (Table 3). Compared to the well-known bevirimat, compound $\mathbf{1 6}$ showed an 

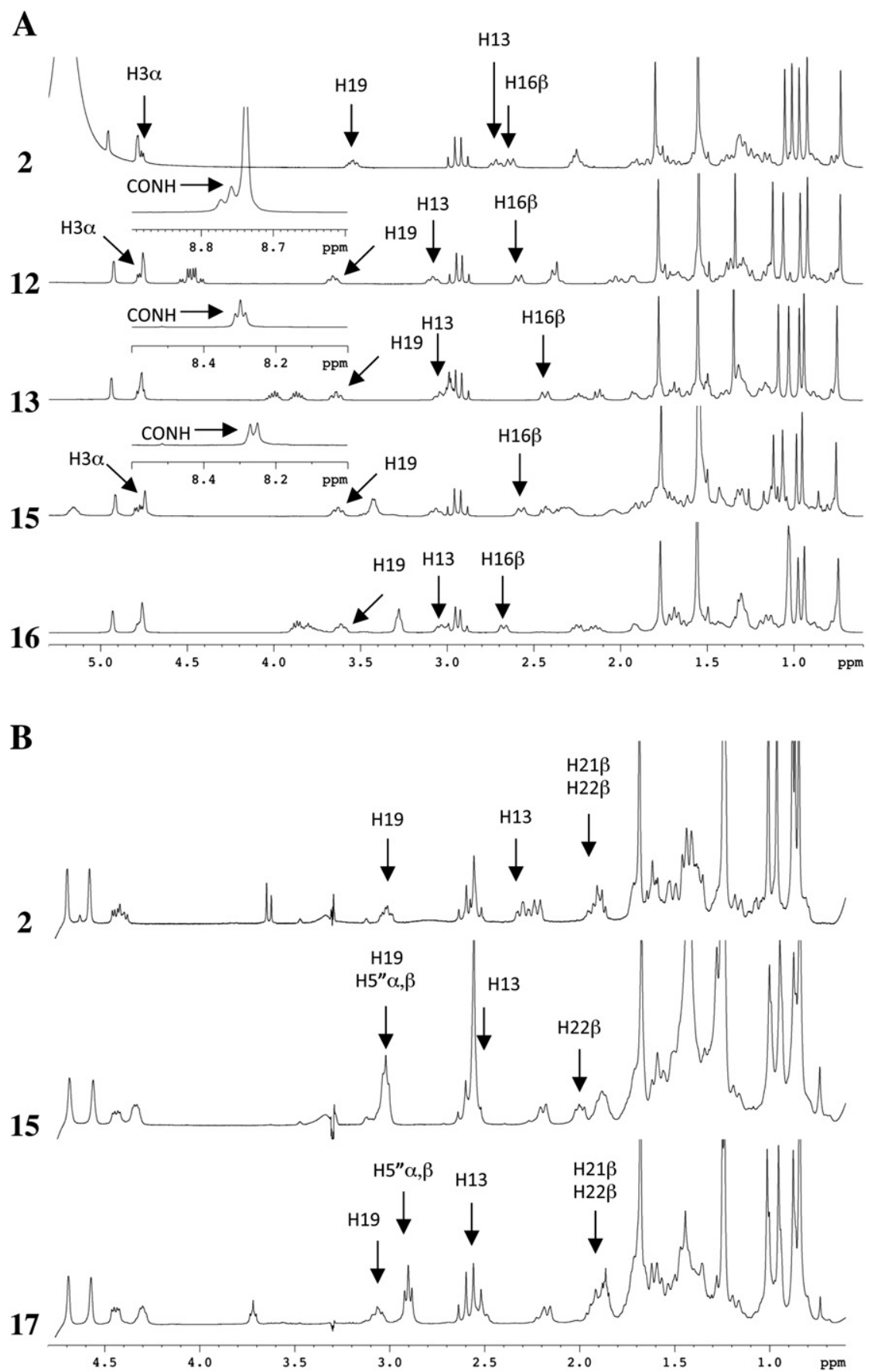

Fig. 3. One-dimensional ${ }^{1} \mathrm{H}$ NMR spectra of bevirimat (2) and derivatives. A. Derivatives 2, 12, 13, 15 and $\mathbf{1 6}$ in pyridine $-\mathrm{d} 5$. B. Derivatives $\mathbf{2}, \mathbf{1 5}$ and $\mathbf{1 7}$ in MeOH-d4.

improved capacity to inhibit p25 maturation with a selectivity index which is twice that of bevirimat and represents an attractive promising HIV-1 inhibitor lead for future clinical trials. The in vitro efficacy of compound 16 against HIV-1 seems to be related to its polarity and we assume that it is possible to improve the activity of these molecules by increasing their polarity and subsequently their hydrosolubility.

Since the solubility of our molecules has been increased by adding hydrophilic functions at the $\mathrm{C}-28$ position, the resolution of a complex between the junction CA-SP1-NC and one of these new molecules becomes feasible. The elucidation of such complexes could help to elucidate the molecular bases required for the inhibition of HIV-1 maturation by bevirimat and its derivatives. The structure of that complex may help to explain how the natural polymorphism and mutations in the spacer peptide SP1 lead to resistance to maturation inhibitors [53-58].

\section{Conclusions}

Bevirimat derived compounds reported in the present study display an increased hydrosolubility generated by the addition of various hydrophilic substituents at the $\mathrm{C}-28$ position. All the new compounds still behave as maturation inhibitors but compound $\mathbf{1 6}$ showed a significant improvement in anti-HIV-1 activity compared to the original bevirimat. Moreover, compound $\mathbf{1 6}$ was shown to interact with the peptide CA-SP1-NC by NMR. This direct 


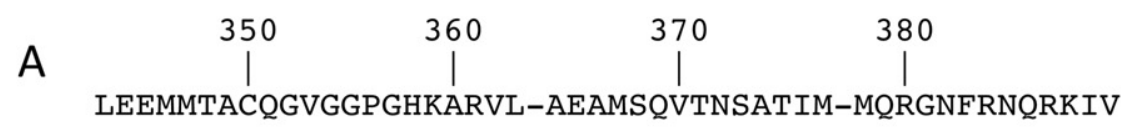
$(343-363) \mathrm{CA}$
$(364-377)$ SP 1
$(378-390) N C$

B
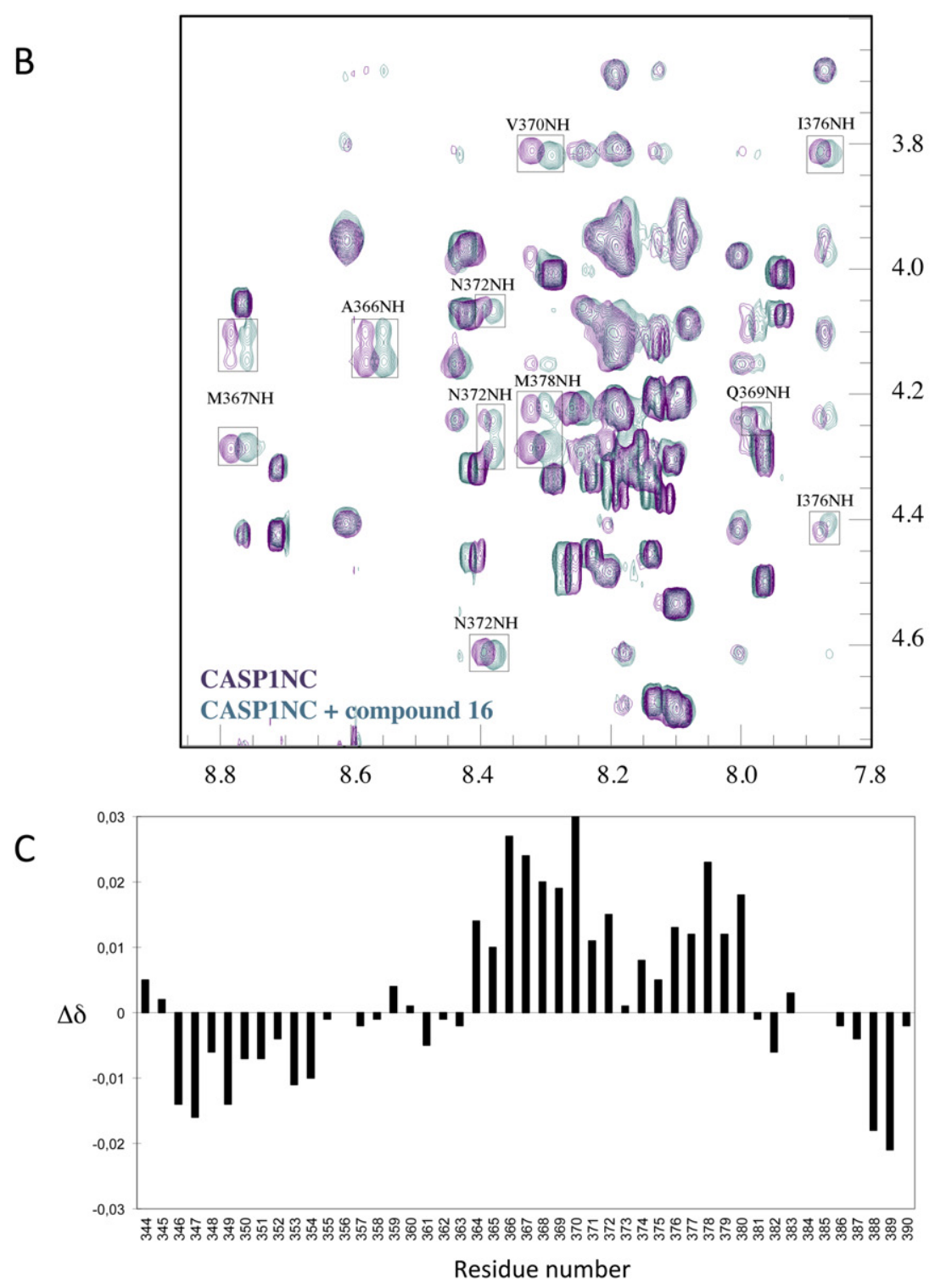

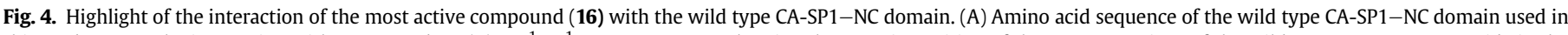

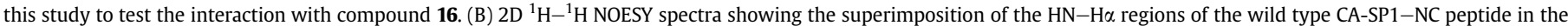

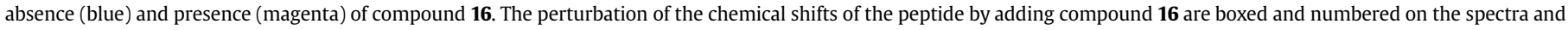

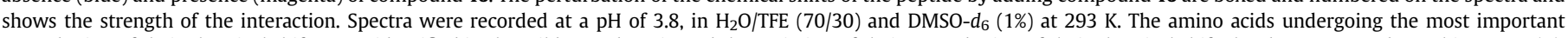

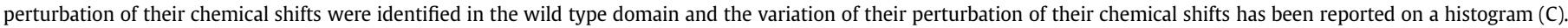
(For interpretation of the references to color in this figure legend, the reader is referred to the web version of this article.)

interaction between a maturation inhibitor and its target is revealed for the first time by NMR and launches the field to the design of new molecules based on the substitution at the C-28 position by hydrophilic groups. Beside the undeniable interest of this property for future use as anti-HIV- 1 molecules, it paves the way to the resolution of complexes formed between derivatives of bevirimat and CA-SP1-NC. The elucidation of such complexes will help clarifying the mechanism accounting for HIV-1 maturation inhibition by this class of compounds and will help to explain how the natural polymorphism of the SP1 domain leads to the resistance to maturation inhibitors. Bevirimat was launched by Panacos Pharmaceuticals, Inc. $[39,40]$ and later by Myriad Pharmaceuticals. Recently, bevirimat succeeded in Phase Ila clinical trials and despite the encouraging results obtained in Phase IIb clinical trials, the development on this new class of anti-HIV drug was interrupted principally because of the natural polymorphism of the CA-SP1 junction that leads to a natural resistance of the virus to maturation inhibitors. The new compounds reported herein, represent attractive and promising leads for future development of the next generation of HIV-1 maturation inhibitors. Once their interaction 
Table 3

Efficiency of HIV-1 infection inhibition by betulinic acid derivatives. ${ }^{a}$

\begin{tabular}{llcr}
\hline Compound & $\mathrm{IC}_{50}(\mu \mathrm{M})$ & $\mathrm{CC}_{50}(\mu \mathrm{M})$ & \multicolumn{1}{c}{$\mathrm{SI}^{\mathrm{b}}$} \\
\hline$(\mathbf{1})$ & 5.315 & 4.52 & 0.85 \\
$(\mathbf{2})$ & 0.040 & 31.0 & 775.00 \\
$(\mathbf{1 2})$ & 0.160 & 49.5 & 309.37 \\
$(\mathbf{1 3})$ & 0.118 & 48.5 & 411.01 \\
$(\mathbf{1 5})$ & 0.170 & 33.9 & 199.41 \\
$(\mathbf{1 6})$ & 0.016 & 33.9 & 2118.75 \\
$(\mathbf{1 7})$ & 4.330 & 48.7 & 11.24 \\
\hline
\end{tabular}

a The mean values $(\mathrm{m})$ for the $50 \%$ inhibitory activity $\left(\mathrm{IC}_{50}\right)$ of infection were given as $\mu \mathrm{M}(\mathrm{m})$. The mean values (m) for cytotoxicity (CC50) were given as $\mu \mathrm{M}(\mathrm{m})$.

$\mathrm{b}$ The selectivity index $(\mathrm{SI})$ represented the $\mathrm{CC}_{50} / \mathrm{IC}_{50}$ ratio.

with the CA-SP1 junction is fully characterized, these inhibitors will serve as model to build new molecules conserving important functions but not necessarily based on a triterpenic skeleton.

\section{Material and methods}

\subsection{Chemistry}

\subsubsection{Generals}

BA, acetic anhydride, PyBOP, DIEA, DMAP, 2,2-dimethylsuccinic anhydride, 2,6-lutidine, tert-butyldimethylsilyltrifluoromethanesulfonate were purchased from Aldrich. All amino acids, from Bachem were $O{ }^{-}{ }^{t} \mathrm{Bu}$ protected and the lysine side chain was protected as $\mathrm{N}$-Boc. The final compounds were characterized by ${ }^{1} \mathrm{H}$ and ${ }^{13} \mathrm{C}$ NMR and high resolution mass spectrometry experiments (Bruker MicrOTof-Q 2 system). Their purity was determined to be $\geq 95 \%$ by elemental analyses $(\mathrm{C}, \mathrm{H}, \mathrm{N})$.

\subsubsection{General procedure for the synthesis of derivatives 4-7}

PyBOP $(0.31-0.47 \mathrm{~g}, 0.6-0.9 \mathrm{mmol})$ and the appropriate amine (0.6-0.9 mmol) were successively added to a mixture of 3-O-Ac-BA (3) (200-300 mg, 0.4-0.6 mmol) and DIEA (0.28-0.42 mL, $1.6-$ $2.4 \mathrm{mmol})$ in DMF $(2-3 \mathrm{~mL})$. The mixture was stirred for $72 \mathrm{~h}$ and then diluted with $\mathrm{CH}_{2} \mathrm{Cl}_{2}(50 \mathrm{~mL})$, washed with aqueous citric acid solution (10\%), water, brine and dried over $\mathrm{MgSO}_{4}$. The organic layer was concentrated under vacuum and the residue was purified by silica gel chromatography to provide the corresponding C28 intermediates.

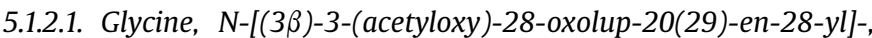
1-(1,1-dimethylethyl) ester (4). $R_{f}$ : 0.38 (toluene/acetone 10/0.5); Yield: $64 \%$ (158 mg); ${ }^{1} \mathrm{H}$ NMR $\left(300 \mathrm{MHz}, \mathrm{CDCl}_{3}\right): \delta 0.75(\mathrm{~m}, 1 \mathrm{H},-\mathrm{CH}$ in 5), $0.82\left(\mathrm{~s}, 3 \mathrm{H},-\mathrm{CH}_{3}\right), 0.83\left(\mathrm{~s}, 3 \mathrm{H},-\mathrm{CH}_{3}\right), 0.91\left(\mathrm{~s}, 3 \mathrm{H},-\mathrm{CH}_{3}\right), 0.95$ $\left(\mathrm{s}, 3 \mathrm{H},-\mathrm{CH}_{3}\right), 1,09(\mathrm{~m}, 2 \mathrm{H}), 1.10-1.45(\mathrm{~m}, 11 \mathrm{H}), 1.47\left(\mathrm{~s}, 12 \mathrm{H},-\mathrm{CH}_{3}, \mathrm{t}-\right.$ $\mathrm{Bu}), 1.50-1.65(\mathrm{~m}, 6 \mathrm{H}), 1.67\left(\mathrm{~s}, 3 \mathrm{H},-\mathrm{CH}_{3}\right), 1.75-2.0(\mathrm{~m}, 3 \mathrm{H}), 2.03(\mathrm{~s}$, $\left.3 \mathrm{H},-\mathrm{COCH}_{3}\right), 2.45(\mathrm{dt}, 1 \mathrm{H}, J=3.5 \mathrm{~Hz}, J=13 \mathrm{~Hz}), 3.10(\mathrm{dt}, 1 \mathrm{H}, J=3$. $5 \mathrm{~Hz}, J=11 \mathrm{~Hz}), 3.89\left(\mathrm{~m}, 2 \mathrm{H},-\mathrm{CH}_{2}\right), 4.45(\mathrm{t}, 1 \mathrm{H}, J=7.5 \mathrm{~Hz}), 4.58(\mathrm{~s}$, $1 \mathrm{H},=\mathrm{CH}), 4.73(\mathrm{~s}, 1 \mathrm{H},=\mathrm{CH}), 6.10(\mathrm{t}, 1 \mathrm{H}, J=5.2 \mathrm{~Hz}) .{ }^{13} \mathrm{C} \mathrm{NMR}$ $\left(300 \mathrm{MHz}, \mathrm{CDCl}_{3}\right): \delta 14.6 ; 16.0 ; 16.2 ; 16.5 ; 18.2 ; 19.4 ; 20.9 ; 21.3$;

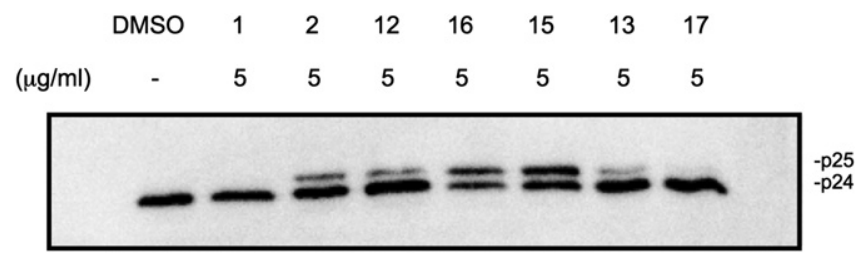

Fig. 5. Effect of the compounds on the virus particle production and Pr55Gag processing was analysed by western blot analysis. Note the accumulation of p25 in the presence of $\mathbf{2}, \mathbf{1 2}, \mathbf{1 6}, \mathbf{1 5}, 13$ and 17.
$23.7 ; 25.5 ; 27.9 ; 28.0 ; 29.4 ; 30.8 ; 33.6 ; 34.3 ; 36.5 ; 37.1 ; 37.6 ; 37.8$; $38.3 ; 38.4 ; 40.7 ; 41.9 ; 42.5 ; 45.9 ; 46.7 ; 50.0 ; 50.5 ; 55.4 ; 55.7 ; 80.9$; $82.0 ; 109.4 ; 150.9 ; 169.6 ; 171.0 ; 176.4$.

5.1.2.2. $\beta$-Alanine, $N$-[(3 3$)$-3-(acetyloxy)-28-oxolup-20(29)-en-28$y l$ l-, 1-(1,1-dimethylethyl) ester (5). $R_{f}$ : 0.45 (toluene/acetone 10/0. 5); Yield: $80 \%$ (300 mg); ${ }^{1} \mathrm{H}$ NMR (400 MHz, $\left.\mathrm{C}_{5} \mathrm{D}_{5} \mathrm{~N}\right): \delta 0.80(\mathrm{~m}, 4 \mathrm{H}$, $-\mathrm{CH}$ in $5,-\mathrm{CH}_{3}$ in 25$), 0.87-0.9\left(\mathrm{~m}, 7 \mathrm{H},-\mathrm{CH}_{3}\right.$ in 23 and $24,-\mathrm{CH}$ in 1), $1.08\left(1 \mathrm{~s}, 3 \mathrm{H},-\mathrm{CH}_{3}\right.$ in 27$), 1.12\left(1 \mathrm{~s}, 3 \mathrm{H},-\mathrm{CH}_{3}\right.$ in 26$), 1.18(\mathrm{~m}, 1 \mathrm{H},-$ $\mathrm{CH}$ in 12$), 1.19(\mathrm{~m}, 1 \mathrm{H},-\mathrm{CH}$ in 11$), 1.21(\mathrm{~m}, 1 \mathrm{H},-\mathrm{CH}$ in 15$), 1.33(\mathrm{~m}$, $1 \mathrm{H},-\mathrm{CH}$ in 9$), 1.34(\mathrm{~m}, 1 \mathrm{H},-\mathrm{CH}$ in 11$), 1.35(\mathrm{~m}, 1 \mathrm{H},-\mathrm{CH}$ in 6$), 1.42$ $(\mathrm{m}, 2 \mathrm{H},-\mathrm{CH}$ in 7$), 1.45(\mathrm{~m}, 1 \mathrm{H},-\mathrm{CH}$ in 6$), 1.49(\mathrm{~s}, 9 \mathrm{H},-\mathrm{COOtBu}), 1.5$ $(\mathrm{m}, 1 \mathrm{H},-\mathrm{CH}$ in 21$), 1.54(\mathrm{~m}, 1 \mathrm{H},-\mathrm{CH}$ in 22$), 1.6(\mathrm{~m}, 2 \mathrm{H},-\mathrm{CH}$ in 1 and 16), $1.65(\mathrm{~m}, 1 \mathrm{H},-\mathrm{CH}$ in 2$), 1.7(\mathrm{~m}, 1 \mathrm{H},-\mathrm{CH}$ in 2$), 1.74(\mathrm{~m}, 1 \mathrm{H},-\mathrm{CH}$ in 15), $1.77\left(\mathrm{~s}, 3 \mathrm{H},-\mathrm{CH}_{3}\right.$ in 30$), 1.94(\mathrm{~m}, 1 \mathrm{H},-\mathrm{CH}$ in 12$), 2.08(\mathrm{~s}, 3 \mathrm{H},-$ $\left.\mathrm{COCH}_{3}\right), 2.13(\mathrm{~m}, 1 \mathrm{H},-\mathrm{CH}$ in 22$), 2.21(\mathrm{~m}, 1 \mathrm{H},-\mathrm{CH}$ in 21$), 2.4(\mathrm{~m}, 1 \mathrm{H}$, $-\mathrm{CH}$ in 16$), 2.77\left(\mathrm{~m}, 1 \mathrm{H},-\mathrm{CH}\right.$ in $\left.2^{\prime \prime}\right), 2.85\left(\mathrm{~m}, 1 \mathrm{H},-\mathrm{CH}\right.$ in $\left.2^{\prime \prime}\right), 3.08(\mathrm{~m}$, $1 \mathrm{H},-\mathrm{CH}$ in 13$), 3.62(\mathrm{~m}, 1 \mathrm{H},-\mathrm{CH}$ in 19$), 3.7\left(\mathrm{~m}, 1 \mathrm{H},-\mathrm{CH}\right.$ in $\left.1^{\prime \prime}\right), 3.85$ $\left(\mathrm{m}, 1 \mathrm{H},-\mathrm{CH}\right.$ in $\left.1^{\prime \prime}\right), 4.7(\mathrm{dd}, 1 \mathrm{H},-\mathrm{CH}$ in $3, J=4.5 \mathrm{~Hz}$ and $11.5 \mathrm{~Hz})$, $4.78(\mathrm{~s}, 1 \mathrm{H},=\mathrm{CH}), 4.94(\mathrm{~s}, 1 \mathrm{H},=\mathrm{CH}), 8.35(\mathrm{~d}, 1 \mathrm{H},-\mathrm{CO}-\mathrm{NH}-$. $J=7 \mathrm{~Hz}) .{ }^{13} \mathrm{C}$ NMR $\left(400 \mathrm{MHz}, \mathrm{C}_{5} \mathrm{D}_{5} \mathrm{~N}\right): \delta 15.2$ (C27); $16.8(\mathrm{C} 25)$; 16.9 (C26); 17.2 (C24); 18.9 (C6); 20 (C30); 21.6 (C2'); 21.66 (C11); 24.5 (C2); 26.6 (C12); 28.5 (3C, $t$-Bu and C23); 30.3 (C15); 31.8 (C21); 34 (C16); 35.1 (C7); 36.3 (C2"); 36.5 (C1" ); 37.7 (C10); 38 (C13); 38.5 (C4); 39 (C22 and C1); 41.6 (C8); 43.2 (C14); 47.65 (C19); 51.1 (C18); 51.3 (C9); 56.1 (C5); 56.3 (C17); 80.7 (Ct-Bu); 81.2 (C3); 110.2 (C29); 152.1 (C20); $171.1\left(\mathrm{C}^{\prime}\right)$; 172.4 (C COOt-Bu); 177.4 (C28).

5.1.2.3. $N$-[(3ß)-3-acetyloxy-lup-20(29)-en-28-oyl]-1,1-dimethylethyl(2-aminoethyl)carbamate (6). $R_{f}: 0.48$ (toluene/acetone 90/10); Yield: $86 \%$ (330 mg); ${ }^{1} \mathrm{H}$ NMR (300 MHz, $\left.\mathrm{CDCl}_{3}\right): \delta 0.77(\mathrm{~m}, 1 \mathrm{H}), 0.83$ $\left(\mathrm{s}, 3 \mathrm{H},-\mathrm{CH}_{3}\right), 0.84\left(\mathrm{~s}, 6 \mathrm{H}, 2-\mathrm{CH}_{3}\right), 0.94\left(\mathrm{~s}, 3 \mathrm{H},-\mathrm{CH}_{3}\right), 0.96(\mathrm{~s}, 3 \mathrm{H},-$ $\left.\mathrm{CH}_{3}\right), 1.09(\mathrm{~m}, 1 \mathrm{H}), 1.10-1.41(\mathrm{~m}, 8 \mathrm{H}), 1.47(\mathrm{~s}, 9 \mathrm{H}, t-\mathrm{Bu}), 1.49-1.65$ $(\mathrm{m}, 8 \mathrm{H}), 1.68\left(\mathrm{~s}, 3 \mathrm{H},-\mathrm{CH}_{3}\right), 1.70-1.80(\mathrm{~m}, 3 \mathrm{H}), 1.98(\mathrm{~m}, 3 \mathrm{H}), 2.04(\mathrm{~s}$, $\left.3 \mathrm{H},-\mathrm{COCH}_{3}\right), 2.45(\mathrm{dt}, 1 \mathrm{H}, J=3.1 \mathrm{~Hz}, J=12.5 \mathrm{~Hz}), 3.13(\mathrm{dt}, 1 \mathrm{H}, J=4$. $4 \mathrm{~Hz}, J=11 \mathrm{~Hz}), 3.27\left(\mathrm{~m}, 2 \mathrm{H},-\mathrm{CH}_{2}\right), 3.34\left(\mathrm{~m}, 2 \mathrm{H},-\mathrm{CH}_{2}\right), 4.46(\mathrm{t}, 1 \mathrm{H}$, $J=7.0 \mathrm{~Hz}), 4.59(\mathrm{~s}, 1 \mathrm{H},=\mathrm{CH}), 4.74(\mathrm{~s}, 1 \mathrm{H},=\mathrm{CH}), 5.04(\mathrm{~m}, 1 \mathrm{H},-\mathrm{NH}-$ $\mathrm{CO}-), 6.33(\mathrm{~m}, 1 \mathrm{H},-\mathrm{CO}-\mathrm{NH}-)$.

5.1.2.4. L-Lysine, $\quad N^{6}$-[(1,1-dimethylethoxy)carbonyl]-, $\quad N^{2}-[(3 \beta)-3-$ (acetyloxy)-28-oxolup-20(29)-en-28-yl]-, 1-(1,1-dimethylethyl) ester (7). $R_{f:} 0.28$ (toluene/acetone 95/5); Yield: $73 \%$ (410 mg); ${ }^{1} \mathrm{H}$ NMR $\left(400 \mathrm{MHz}, \mathrm{C}_{5} \mathrm{D}_{5} \mathrm{~N}\right): \delta 0.80\left(\mathrm{~m}, 4 \mathrm{H},-\mathrm{CH}\right.$ in $5,-\mathrm{CH}_{3}$ in 25$), 0.90(\mathrm{~m}$, $7 \mathrm{H},-\mathrm{CH}_{3}$ in 23 and $24,-\mathrm{CH}$ in 1$), 1.09\left(2 \mathrm{~s}, 6 \mathrm{H},-\mathrm{CH}_{3}\right.$ in 27 and 26), $1.16(\mathrm{~m}, 1 \mathrm{H},-\mathrm{CH}$ in 11$), 1.17(\mathrm{~m}, 1 \mathrm{H},-\mathrm{CH}$ in 12$), 1.29(\mathrm{~m}, 1 \mathrm{H},-\mathrm{CH}$ in 15), $1.32(\mathrm{~m}, 1 \mathrm{H},-\mathrm{CH}$ in 11$), 1.33(\mathrm{~m}, 1 \mathrm{H},-\mathrm{CH}$ in 9$), 1.42(\mathrm{~m}, 3 \mathrm{H},-\mathrm{CH}$ in 6 and 7$), 1.48(\mathrm{~s}, 9 \mathrm{H},-\mathrm{COOtBu}$ and $\mathrm{m}, 1 \mathrm{H},-\mathrm{CH}$ in 6$), 1.52(\mathrm{~m}, 2 \mathrm{H}$, $-\mathrm{CH}$ in 21 and 22), $1.55(\mathrm{~s}, 9 \mathrm{H},-\mathrm{NHBoc}), 1.58(\mathrm{~m}, 2 \mathrm{H},-\mathrm{CH}$ in 1 and 2), $1.69\left(\mathrm{~m}, 2 \mathrm{H},-\mathrm{CH}_{2 \gamma}\right.$ Lys $), 1.70\left(\mathrm{~m}, 3 \mathrm{H},-\mathrm{CH}\right.$ in $18,-\mathrm{CH}_{2 \delta}$ Lys $), 1.71$ $(\mathrm{m}, 1 \mathrm{H},-\mathrm{CH}$ in 2$), 1.78\left(\mathrm{~s}, 3 \mathrm{H},-\mathrm{CH}_{3}\right.$ in 30$), 1.80(\mathrm{~m}, 1 \mathrm{H},-\mathrm{CH}$ in 15$)$, $1.86\left(\mathrm{~m}, 1 \mathrm{H},-\mathrm{CH}_{\beta}\right.$ Lys $), 1.92(\mathrm{~m}, 1 \mathrm{H},-\mathrm{CH}$ in 12$), 2.07\left(\mathrm{~m}, 1 \mathrm{H},-\mathrm{CH}_{\beta}\right.$ Lys $), 2.08\left(\mathrm{~s}, 3 \mathrm{H},-\mathrm{COCH}_{3}\right), 2.30(\mathrm{~m}, 1 \mathrm{H},-\mathrm{CH}$ in 21$), 2.33(\mathrm{~m}, 1 \mathrm{H},-\mathrm{CH}$ in 22), $2.54(\mathrm{~m}, 1 \mathrm{H},-\mathrm{CH}$ in 16$), 3.03(\mathrm{~m}, 1 \mathrm{H},-\mathrm{CH}$ in 13$), 3.40(\mathrm{~m}, 2 \mathrm{H}$, $-\mathrm{CH}_{2 \varepsilon}$ Lys), $3.58(\mathrm{~m}, 1 \mathrm{H},-\mathrm{CH}$ in 19$), 4.7(\mathrm{dd}, 1 \mathrm{H},-\mathrm{CH}$ in $3, \mathrm{~J}=5 \mathrm{~Hz}$ and 11. $5 \mathrm{~Hz}), 4.75(\mathrm{~s}, 1 \mathrm{H},=\mathrm{CH}), 4.91\left(\mathrm{~m}, 2 \mathrm{H},=\mathrm{CH}\right.$ and $\left.-\mathrm{CH}_{\alpha} \mathrm{Lys}\right)$, $7.55(\mathrm{t}, 1 \mathrm{H},-\mathrm{NH}-\mathrm{CO}-\mathrm{J}=5 \mathrm{~Hz}), 8.22(\mathrm{~d}, 1 \mathrm{H},-\mathrm{CO}-\mathrm{NH}-\mathrm{J}=8 \mathrm{~Hz})$. ${ }^{13} \mathrm{C}$ NMR (400 MHz, C5 $\left.\mathrm{D}_{5} \mathrm{~N}\right): \delta 15.3$ (C27); 16.7 (C25); 17 (C26); 17.2 (C24); 19 (C6); 20 (C30); 21.6 (C2'); 21.7 (C11); 24.3 (C $\gamma$ Lys); 24.5 (C2); 26. 6 (C12); 28.4 (3C, t-Bu); 28.5 (C23); 29 (3C, Boc); 30.3 (C15); 30.5(C $\delta$ Lys); 31.9 (C21); 32 (C $\beta$ Lys); 34 (C16); 35.1 (C7); 37.8 (C10); 38.1 (C13); 38.5(C4); 38.65 (C22); 39 (C1); 41.3 (CELys); 41.6 (C8); 43.2 (C14); 47.6 (C19); 51.1 (C18); 51.3 (C9); 53.4 (C $\alpha$ Lys); 56.1 (C5); 56.4 (C17); 78.4 (CBoc); 81.2 (C3); 81.3 (Ct-Bu); 110.2 (C29); 152.1 (C20); 157.25 (C NHCOOt-Bu); $171.1\left(\mathrm{C1}^{\prime}\right)$; 173.4 (C COOt-Bu); 177.3 (C28). 


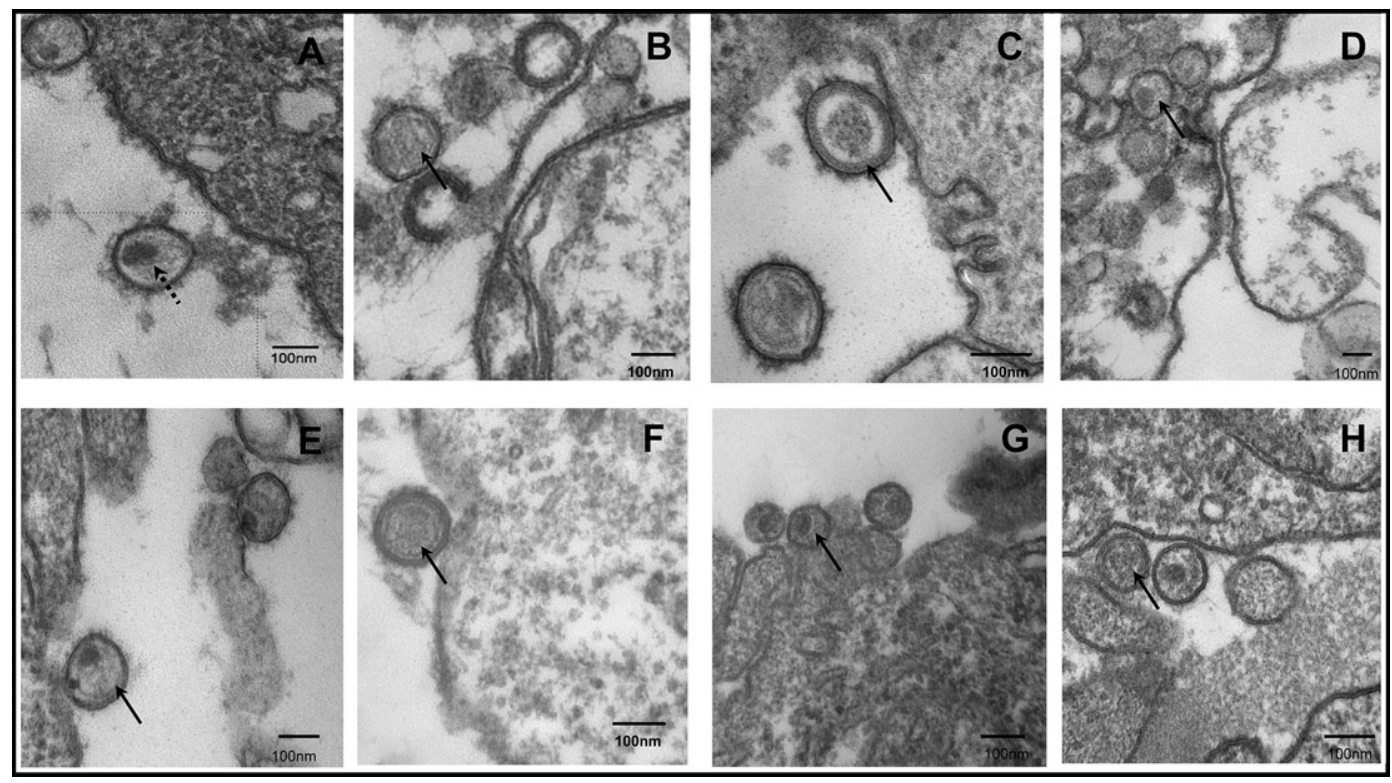

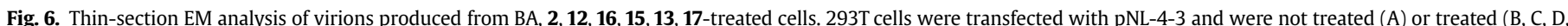

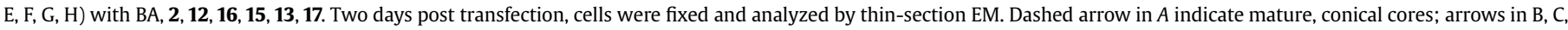
$\mathrm{D}, \mathrm{E}, \mathrm{F}, \mathrm{G}, \mathrm{H}$ indicate the crescent-shaped, electron-dense layer inside the viral membrane that results from inhibition of p25 processing. (Bar: $\approx 100 \mathrm{~nm}$ ).

\subsubsection{General procedure for the synthesis of derivative 8-11}

An aqueous $\mathrm{NaOH}(4 \mathrm{M}, 0.75 \mathrm{~mL})$ was added to the solution of the above intermediates $(0.3 \mathrm{mmol})$ in $\mathrm{THF} / \mathrm{MeOH}(1 / 1.4 \mathrm{~mL})$. After stirring for $12 \mathrm{~h}$ at room temperature, the mixture was acidified with $1 \mathrm{M} \mathrm{HCl}$. The resulting precipitate was collected, washed with water and dried over vacuum to yield the corresponding compounds 8 and 9. For compounds $\mathbf{1 0}$ and 11, the mixture was extracted with $\mathrm{CH}_{2} \mathrm{Cl}_{2}(50 \mathrm{~mL})$, the organic layer was washed with water, brine and dried over $\mathrm{MgSO}_{4}$ and then concentrated under vacuum. The residue was purified by silica gel chromatography to provide the corresponding derivatives.

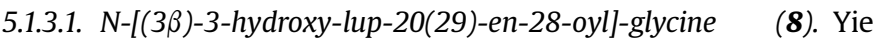
ld: $83 \%(128 \mathrm{mg}) ;{ }^{1} \mathrm{H}$ NMR $\left(\mathrm{CDCl}_{3}\right): \delta 0.70(\mathrm{~m}, 1 \mathrm{H},-\mathrm{CH}$ in 5$), 0.77(\mathrm{~s}$, $\left.3 \mathrm{H},-\mathrm{CH}_{3}\right), 0.83\left(\mathrm{~s}, 3 \mathrm{H},-\mathrm{CH}_{3}\right), 0.93\left(\mathrm{~s}, 3 \mathrm{H},-\mathrm{CH}_{3}\right), 0.98\left(\mathrm{~s}, 3 \mathrm{H},-\mathrm{CH}_{3}\right)$, $0.99\left(\mathrm{~s}, 3 \mathrm{H},-\mathrm{CH}_{3}\right), 1.09(\mathrm{~m}, 1 \mathrm{H}), 1.10-1.65(\mathrm{~m}, 20 \mathrm{H}), 1.70(\mathrm{~s}, 3 \mathrm{H},-$ $\left.\mathrm{CH}_{3}\right), 1.90(\mathrm{~m}, 3 \mathrm{H}), 2.40(\mathrm{dt}, 1 \mathrm{H}, J=3.5 \mathrm{~Hz}, J=13 \mathrm{~Hz}), 3.10(\mathrm{dt}, 1 \mathrm{H}$, $J=3.5 \mathrm{~Hz}, J=11 \mathrm{~Hz}), 3.20(\mathrm{~m}, 1 \mathrm{H}), 4.05(\mathrm{t}, 2 \mathrm{H}, J=7.5 \mathrm{~Hz}), 4.61(\mathrm{~s}, 1 \mathrm{H}$, $=\mathrm{CH}), 4.75(\mathrm{~s}, 1 \mathrm{H},=\mathrm{CH}), 6.14(\mathrm{t}, 1 \mathrm{H}, J=5.2 \mathrm{~Hz})$.

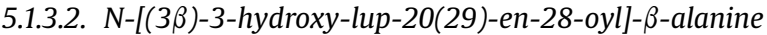

Yield: $89 \%(141 \mathrm{mg}) ;{ }^{1} \mathrm{H}$ NMR $\left(400 \mathrm{MHz}, \mathrm{C}_{5} \mathrm{D}_{5} \mathrm{~N}\right): \delta 0.86(\mathrm{~m}, 1 \mathrm{H},-$ $\mathrm{CH}$ in 5), $0.88\left(\mathrm{~m}, 3 \mathrm{H},-\mathrm{CH}_{3}\right.$ in 25$), 0.99(\mathrm{~m}, 1 \mathrm{H},-\mathrm{CH}$ in 1$), 1.04(\mathrm{~s}$, $3 \mathrm{H},-\mathrm{CH}_{3}$ in 24$), 1.08\left(\mathrm{~s}, 3 \mathrm{H},-\mathrm{CH}_{3}\right.$ in 27$), 1.16\left(\mathrm{~s}, 3 \mathrm{H},-\mathrm{CH}_{3}\right.$ in 26$), 1.2$ $(\mathrm{m}, 1 \mathrm{H},-\mathrm{CH}$ in 12$), 1.24(\mathrm{~m}, 2 \mathrm{H},-\mathrm{CH}$ in 11 and $-\mathrm{CH}$ in 15$), 1.27(\mathrm{~m}$, $3 \mathrm{H},-\mathrm{CH}_{3}$ in 23$), 1.41(\mathrm{~m}, 3 \mathrm{H},-\mathrm{CH}$ in 6 and $-\mathrm{CH}$ in 7$), 1.42(\mathrm{~m}, 1 \mathrm{H},-$ $\mathrm{CH}$ in 9$), 1.44(\mathrm{~m}, 1 \mathrm{H},-\mathrm{CH}$ in 11$), 1.5(\mathrm{~m}, 2 \mathrm{H},-\mathrm{CH}$ in 21 and $-\mathrm{CH}$ in 22), $1.58(\mathrm{~m}, 2 \mathrm{H},-\mathrm{CH}$ in 6 and $-\mathrm{CH}$ in 16$), 1.68(\mathrm{~m}, 1 \mathrm{H},-\mathrm{CH}$ in 1$)$, $1.72(\mathrm{~m}, 1 \mathrm{H},-\mathrm{CH}$ in 18$), 1.8\left(\mathrm{~s}, 3 \mathrm{H},-\mathrm{CH}_{3}\right.$ in 30$), 1.86(\mathrm{~m}, 1 \mathrm{H},-\mathrm{CH}$ in 15), $1.89(\mathrm{~m}, 2 \mathrm{H},-\mathrm{CH}$ in 2$), 1.98(\mathrm{~m}, 1 \mathrm{H},-\mathrm{CH}$ in 12$), 2.13(\mathrm{~m}, 1 \mathrm{H},-$ $\mathrm{CH}$ in 22$), 2.28(\mathrm{~m}, 1 \mathrm{H},-\mathrm{CH}$ in 21$), 2.44(\mathrm{~m}, 1 \mathrm{H},-\mathrm{CH}$ in 16$), 2.96(\mathrm{~m}$, $2 \mathrm{H},-\mathrm{CH}$ in $\left.2^{\prime \prime}\right), 3.05(\mathrm{~m}, 1 \mathrm{H},-\mathrm{CH}$ in 13$), 3.46(\mathrm{~m}, 1 \mathrm{H},-\mathrm{CH}$ in 3$)$, $3.65(\mathrm{~m}, 1 \mathrm{H},-\mathrm{CH}$ in 19$), 3.93\left(\mathrm{~m}, 1 \mathrm{H},-\mathrm{CH}\right.$ in $\left.1^{\prime \prime}\right), 3.98(\mathrm{~m}, 1 \mathrm{H},-\mathrm{CH}$ in $\left.1^{\prime \prime}\right), 4.77(\mathrm{~s}, 1 \mathrm{H},=\mathrm{CH}), 4.93(\mathrm{~s}, 1 \mathrm{H},=\mathrm{CH}), 8.36(\mathrm{~d}, 1 \mathrm{H},-\mathrm{CO}-\mathrm{NH}-$. $J=7 \mathrm{~Hz}) .{ }^{13} \mathrm{C}$ NMR $\left(400 \mathrm{MHz}, \mathrm{C}_{5} \mathrm{D}_{5} \mathrm{~N}\right): \delta 16.2$ (C27); $17.8(\mathrm{C} 24)$; 17.86 (C25); 17.92 (C26); 20.2 (C6); 21 (C30); 22.6 (C11); 27.6 (C12); 29.7 (C2); 30 (C23); 31.2 (C15); 32.8 (C21); 35 (C16); 36.2 (C7); 37.4 (C2"); 37.9 (C1" ); 38.9 (C10); 39.2 (C13); 40.1 (C22); 40.6 (C1); 40.9
(C4); 42.6 (C8); 44.1 (C14); 48.7 (C19); 52.1 (C18); 52.4 (C9); 57.28 (C17); 57.34 (C5); 79.5 (C3); 110.1 (C29); 153.1 (C20); 177.5 (C3"); $178.1(\mathrm{C} 28)$.

5.1.3.3. $N$-[(3ß)-3-hydroxy-lup-20(29)-en-28-oyl]-1,1-dimethylethyl(2-aminoethyl)carbamate (10). $R_{f}: 0.48$ (toluene/acetone $80 / 20$ ); Yield 67\% (210 mg); ${ }^{1} \mathrm{H}$ NMR (300 MHz, $\left.\mathrm{CDCl}_{3}\right): \delta 0.70(\mathrm{~m}, 1 \mathrm{H},-\mathrm{CH}$ in 5), $0.77\left(\mathrm{~s}, 3 \mathrm{H},-\mathrm{CH}_{3}\right), 0.83\left(\mathrm{~s}, 3 \mathrm{H},-\mathrm{CH}_{3}\right), 0.94\left(\mathrm{~s}, 3 \mathrm{H},-\mathrm{CH}_{3}\right), 0.97$ $\left(\mathrm{s}, 6 \mathrm{H}, 2-\mathrm{CH}_{3}\right), 1.09(\mathrm{~m}, 1 \mathrm{H}), 1.10-1.40(\mathrm{~m}, 9 \mathrm{H}), 1.45(\mathrm{~s}, 9 \mathrm{H}, t-\mathrm{Bu})$ 1.50-1.65 (m, 7H), $1.69\left(\mathrm{~s}, 3 \mathrm{H},-\mathrm{CH}_{3}\right), 1.72(\mathrm{~m}, 3 \mathrm{H}), 1.99(\mathrm{~m}, 2 \mathrm{H}), 2$. $46(\mathrm{dt}, 1 \mathrm{H}, J=3.5 \mathrm{~Hz}, J=13 \mathrm{~Hz}), 3.20(\mathrm{~m}, 6 \mathrm{H}), 3.20(\mathrm{~m}, 1 \mathrm{H}), 4.60(\mathrm{~s}$, $1 \mathrm{H},=\mathrm{CH}), 4.74(\mathrm{~s}, 1 \mathrm{H},=\mathrm{CH}), 5.01(\mathrm{~m}, 1 \mathrm{H},-\mathrm{NH}-\mathrm{CO}-), 6.33(\mathrm{~m}, 1 \mathrm{H}$, $-\mathrm{CO}-\mathrm{NH}-$ ).

5.1.3.4. $N^{6}-\left[\left(1,1-\right.\right.$ dimethylethoxy)carbonyl], $N^{2}-[(3 \beta)-3$-hydroxy-lup20(29)-en-28-oyl]-L-lysine (11). $R_{f}$ : 0.32 (n-heptane/ethyl acetate/ acetic acid 10/10/0.25); Yield 97\% (277 mg); ${ }^{1} \mathrm{H}$ NMR (400 MHz, $\left.\mathrm{C}_{5} \mathrm{D}_{5} \mathrm{~N}\right): \delta 0.86\left(\mathrm{~m}, 4 \mathrm{H},-\mathrm{CH}\right.$ in $5,-\mathrm{CH}_{3}$ in 25$), 1.02(\mathrm{~m}, 1 \mathrm{H},-\mathrm{CH}$ in 1$)$, $1.06\left(\mathrm{~s}, 3 \mathrm{H},-\mathrm{CH}_{3}\right.$ in 24$), 1.10\left(\mathrm{~s}, 3 \mathrm{H},-\mathrm{CH}_{3}\right.$ in 27$), 1.18\left(\mathrm{~s}, 3 \mathrm{H},-\mathrm{CH}_{3}\right.$ in 26), $1.20(\mathrm{~m}, 1 \mathrm{H},-\mathrm{CH}$ in 12$), 1.22(\mathrm{~m}, 1 \mathrm{H},-\mathrm{CH}$ in 11$), 1.26(\mathrm{~s}, 3 \mathrm{H},-$ $\mathrm{CH}_{3}$ in 23$), 1.35(\mathrm{~m}, 1 \mathrm{H},-\mathrm{CH}$ in 15$), 1.42(\mathrm{~m}, 1 \mathrm{H},-\mathrm{CH}$ in 11$), 1.43(\mathrm{~m}$, $1 \mathrm{H},-\mathrm{CH}$ in 9$), 1.48(\mathrm{~m}, 1 \mathrm{H},-\mathrm{CH}$ in 6$), 1.50\left(\mathrm{~m}, 2 \mathrm{H},-\mathrm{CH}_{2}\right.$ in 7$), 1.52$ $(\mathrm{m}, 1 \mathrm{H},-\mathrm{CH}$ in 21$), 1.53(\mathrm{~m}, 1 \mathrm{H},-\mathrm{CH}$ in 22$), 1.55(\mathrm{~s}, 9 \mathrm{H},-\mathrm{NHBoc})$, $1.61(\mathrm{~m}, 1 \mathrm{H},-\mathrm{CH}$ in 6$), 1.67(\mathrm{~m}, 1 \mathrm{H},-\mathrm{CH}$ in 16$), 1.70(\mathrm{~m}, 1 \mathrm{H},-\mathrm{CH}$ in 1$), 1.75(\mathrm{~m}, 1 \mathrm{H},-\mathrm{CH}$ in 18$), 1.77\left(\mathrm{~s}, 3 \mathrm{H},-\mathrm{CH}_{3}\right.$ in 30$), 1.80(\mathrm{~m}$, $2 \mathrm{H},-\mathrm{CH}_{2 \delta}$ Lys), $1.81\left(\mathrm{~m}, 2 \mathrm{H},-\mathrm{CH}_{2 \gamma}\right.$ Lys), $1.88\left(\mathrm{~m}, 2 \mathrm{H},-\mathrm{CH}_{2}\right.$ in 2$), 1.91$ $(\mathrm{m}, 1 \mathrm{H},-\mathrm{CH}$ in 15$), 1.96(\mathrm{~m}, 1 \mathrm{H},-\mathrm{CH}$ in 12$), 2.05\left(\mathrm{~m}, 1 \mathrm{H},-\mathrm{CH}_{\beta}\right.$ Lys), $2.30\left(\mathrm{~m}, 1 \mathrm{H},-\mathrm{CH}_{\beta}\right.$ Lys $), 2.36(\mathrm{~m}, 1 \mathrm{H},-\mathrm{CH}$ in 21$), 2.45(\mathrm{~m}, 1 \mathrm{H},-\mathrm{CH}$ in 22), $2.58(\mathrm{~m}, 1 \mathrm{H},-\mathrm{CH}$ in 16$), 3.09(\mathrm{~m}, 1 \mathrm{H},-\mathrm{CH}$ in 13$), 3.43(\mathrm{~m}, 2 \mathrm{H},-$ $\mathrm{CH}_{2 \varepsilon}$ Lys), $3.49(\mathrm{~m}, 1 \mathrm{H},-\mathrm{CH}$ in 3$), 3.65(\mathrm{~m}, 1 \mathrm{H},-\mathrm{CH}$ in 19$), 4.77$ (s, $1 \mathrm{H},=\mathrm{CH}$ in 29), $4.92(\mathrm{~s}, 1 \mathrm{H},=\mathrm{CH}$ in 29$), 5.16\left(\mathrm{~m}, 1 \mathrm{H},-\mathrm{CH}_{\alpha}\right.$ Lys $), 7.58$ $(\mathrm{m}, 1 \mathrm{H},-\mathrm{NH}-\mathrm{CO}-), 8.25(\mathrm{~d}, 1 \mathrm{H},-\mathrm{CO}-\mathrm{NH}-, J=8 \mathrm{~Hz}) .{ }^{13} \mathrm{C}$ NMR (400 MHz, $\mathrm{C}_{5} \mathrm{D}_{5} \mathrm{~N}$ ): $\delta 15.3$ (C27); 16.85 (C24); 17 (C25); 17.1 (C26); 19.3 (C6); 20 (C30); 21.7 (C11); 24.5 (CyLys); 26.7 (C12); 28.8 (C2); 29.1 (3C, Boc); 29.2(C23); 30.4 (C15); 30.6 (CoLys); 31.9 (C21); 32.5 (CßLys); 34.2 (C16); 35.4 (C7); 38 (C10); 38.2 (C13); 38.8 (C22); 39.75 (C1); 40 (C4); 41.4 (CELys); 41.7 (C8); 43.2 (C14); 47.7 (C19); 51.2 (C18); 51.6 (C9); 53 (CaLys); 56.4 (C5); 56.6 (C17); 78,4 (3CBoc); 
78.6 (C3); 110.1 (C29); 152.2 (C20); 157.3 (C, NHCOOt-Bu); 176.6 (C, $\mathrm{COOH}) ; 177.4(\mathrm{C} 28)$.

\subsubsection{General procedure for the synthesis of derivatives 12-15}

A mixture of the above intermediates $(\mathbf{8}, \mathbf{9}, 10$ or $\mathbf{1 1}), 2,2-$ dimethylsuccinic anhydride (10 equiv) and DMAP (1 equiv) in anhydrous pyridine $(20 \mathrm{~mL} / \mathrm{mmol})$ was refluxed overnight. The mixture was then concentrated under vacuum and the residue was chromatographed on silica gel to yield the derivatives 12,13,14 and 15.

5.1.4.1. N-[(3ß)-3-(3-carboxy-3-methylbutanoyloxy)lup-20(29)-en28-oyl-glycine (12). $R_{f}$ : 0.23 dichloromethane/methanol/acetic acid (10/0.1/0.02); Yield 58\% (80 mg); HRMS (ESI) calcd for $\mathrm{C}_{38} \mathrm{H}_{58} \mathrm{NO}_{7}[\mathrm{M}-\mathrm{H}]^{-} 640.4219$ found $640.4232 ;{ }^{1} \mathrm{H}$ NMR $(400 \mathrm{MHz}$, $\left.\mathrm{C}_{5} \mathrm{D}_{5} \mathrm{~N}\right): \delta 0.73\left(\mathrm{~s}, 3 \mathrm{H},-\mathrm{CH}_{3}\right.$ in 25$), 0.77(\mathrm{~m}, 1 \mathrm{H},-\mathrm{CH}$ in 5$), 0.89(\mathrm{~m}$, $1 \mathrm{H},-\mathrm{CH}$ in 1$), 0.92\left(\mathrm{~s}, 3 \mathrm{H},-\mathrm{CH}_{3}\right.$ in 24$), 0.96\left(\mathrm{~s}, 3 \mathrm{H},-\mathrm{CH}_{3}\right.$ in 23$)$, $1.06\left(\mathrm{~s}, 3 \mathrm{H},-\mathrm{CH}_{3}\right.$ in 27$), 1.12\left(\mathrm{~s}, 3 \mathrm{H},-\mathrm{CH}_{3}\right.$ in 26$), 1.15(\mathrm{~m}, 1 \mathrm{H},-\mathrm{CH}$ in 12), $1.15(\mathrm{~m}, 1 \mathrm{H},-\mathrm{CH}$ in 11$), 1.26(\mathrm{~m}, 1 \mathrm{H},-\mathrm{CH}$ in 15$), 1.30(\mathrm{~m}, 2 \mathrm{H},-$ $\mathrm{CH}$ in $9,-\mathrm{CH}$ in 11$), 1.30-1.40\left(\mathrm{~m}, 4 \mathrm{H},-\mathrm{CH}_{2}\right.$ in $6,-\mathrm{CH}_{2}$ in 7$), 1.52$ $(\mathrm{m}, 1 \mathrm{H},-\mathrm{CH}$ in 1$), 1.54(\mathrm{~m}, 1 \mathrm{H},-\mathrm{CH}$ in 21$), 1.55\left(\mathrm{~s}, 3 \mathrm{H},-\mathrm{CH}_{3}\right.$ in $\left.5^{\prime}\right)$, $1.59(\mathrm{~m}, 1 \mathrm{H},-\mathrm{CH}$ in 22$), 1.67(\mathrm{~m}, 2 \mathrm{H},-\mathrm{CH}$ in $2,-\mathrm{CH}$ in 16$), 1.74(\mathrm{~m}$, $1 \mathrm{H},-\mathrm{CH}$ in 18$), 1.77(\mathrm{~m}, 1 \mathrm{H},-\mathrm{CH}$ in 2$), 1.78\left(\mathrm{~s}, 3 \mathrm{H},-\mathrm{CH}_{3}\right.$ in 30$), 1.93$ $(\mathrm{m}, 1 \mathrm{H},-\mathrm{CH}$ in 12$), 2.03(\mathrm{~m}, 1 \mathrm{H},-\mathrm{CH}$ in 15$), 2.38(\mathrm{~m}, 1 \mathrm{H},-\mathrm{CH}$ in 21), $2.39(\mathrm{~m}, 1 \mathrm{H},-\mathrm{CH}$ in 22$), 2.59(\mathrm{~m}, 1 \mathrm{H},-\mathrm{CH}$ in 16$), 2.91(\mathrm{~d}, 1 \mathrm{H}$, $-\mathrm{CH}$ in $\left.2^{\prime}, J=15.5 \mathrm{~Hz}\right), 2.95\left(\mathrm{~d}, 1 \mathrm{H},-\mathrm{CH}\right.$ in $\left.2^{\prime}, J=15.5 \mathrm{~Hz}\right), 3.08(\mathrm{~m}$, $1 \mathrm{H},-\mathrm{CH}$ in 13$), 3.66(\mathrm{~m}, 1 \mathrm{H},-\mathrm{CH}$ in 19$), 4.44-4.51\left(\mathrm{dd}, 2 \mathrm{H},-\mathrm{CH}_{2}\right.$ in $\left.1^{\prime \prime}, J=6 \mathrm{~Hz}, J=17.5 \mathrm{~Hz}\right), 4.75(\mathrm{~s}, 1 \mathrm{H},-\mathrm{CH}$ in 29$), 4.77(\mathrm{~d}, 1 \mathrm{H},-\mathrm{CH}$ in $3, J=5 \mathrm{~Hz}), 4.96(\mathrm{~s}, 1 \mathrm{H},-\mathrm{CH}$ in 29$), 8.76(\mathrm{t}, 1 \mathrm{H},-\mathrm{NH}-\mathrm{CO}-$, $J=5.5 \mathrm{~Hz}$ ). ${ }^{13} \mathrm{C}$ NMR (400 MHz, $\left.\mathrm{C}_{5} \mathrm{D}_{5} \mathrm{~N}\right): \delta 15.3$ (C27); 16.7 (C25); 17 (C26); 17.3 (C24); 18.9 (C6); 20 (C30); 21.6 (C11); 24.6 (C2); 26.6 (C12); 26.7 (C5'); 28.5 (C23); 30.3 (C15); 31.8 (C21); 34 (C16); 35 (C7); 37.7 (C10); 38.1 (C13); 38.5 (C4); 39 (C1); 39.1 (C22); 41.3 (C3'); 41.6 (C8); $42.4\left(\mathrm{C}^{\prime \prime}\right) ; 43.2$ (C14); $45.6\left(\mathrm{C}^{\prime}\right) ; 47.7$ (C19); 51.0 (C18); 51.2 (C9); 56.0 (C5); 56.4 (C17); 81.4 (C3); 110.3 (C29); 152.2 (C20); 172.1 (C1'); $174\left(\mathrm{C6}^{\prime \prime}\right) ; 177.9$ (C28); 179.8 (C4'). Anal. $\left(\mathrm{C}_{38} \mathrm{H}_{59} \mathrm{NO}_{7} \cdot 0.5 \mathrm{H}_{2} \mathrm{O}\right) \mathrm{C}, \mathrm{H}, \mathrm{N}$.

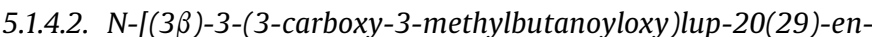
28-oyl]- $\beta$-alanine (13). $R_{f}$ : $0.27 n$-heptane/ethyl acetate/acetic acid (10/10/0.5); Yield 2.62\% (166 mg); HRMS (ESI) calcd for $\mathrm{C}_{39} \mathrm{H}_{60} \mathrm{NO}_{7}$ $[\mathrm{M}-\mathrm{H}]^{-} 654.4375$ found 654.4375 , calcd for $\mathrm{C}_{39} \mathrm{H}_{59} \mathrm{NO}_{7} \mathrm{Na}$ $[\mathrm{M}-2 \mathrm{H}+\mathrm{Na}]^{-} 676.4195$ found $676.4186 ;{ }^{1} \mathrm{H}$ NMR $(400 \mathrm{MHz}$, $\left.\mathrm{C}_{5} \mathrm{D}_{5} \mathrm{~N}\right): \delta 0.74\left(\mathrm{~m}, 1 \mathrm{H},-\mathrm{CH}\right.$ in 5 and $\mathrm{s}, 3 \mathrm{H},-\mathrm{CH}_{3}$ in 25$), 0.91(\mathrm{~m}, 1 \mathrm{H}$, $-\mathrm{CH}$ in 1), $0.94\left(\mathrm{~s}, 3 \mathrm{H},-\mathrm{CH}_{3}\right.$ in 24$), 0.97\left(\mathrm{~s}, 3 \mathrm{H},-\mathrm{CH}_{3}\right.$ in 23$), 1.04(\mathrm{~s}$, $3 \mathrm{H},-\mathrm{CH}_{3}$ in 27$), 1.08\left(\mathrm{~s}, 3 \mathrm{H},-\mathrm{CH}_{3}\right.$ in 26$), 1.17(\mathrm{~m}, 2 \mathrm{H},-\mathrm{CH}$ in 11 and $-\mathrm{CH}$ in 12$), 1.2(\mathrm{~m}, 1 \mathrm{H},-\mathrm{CH}$ in 15$), 1.30(\mathrm{~m}, 2 \mathrm{H},-\mathrm{CH}$ in $9,-\mathrm{CH}$ in 6$)$, $1.31(\mathrm{~m}, 1 \mathrm{H},-\mathrm{CH}$ in 11$), 1.33(\mathrm{~m}, 2 \mathrm{H},-\mathrm{CH}$ in 7$), 1.4(\mathrm{~m}, 1 \mathrm{H},-\mathrm{CH}$ in 6$)$ $1.52(\mathrm{~m}, 2 \mathrm{H},-\mathrm{CH}$ in 21 and $-\mathrm{CH}$ in 22$), 1.55\left(\mathrm{~s}, 3 \mathrm{H},-\mathrm{CH}_{3}\right.$ in $\left.5^{\prime}\right), 1.58$ $(\mathrm{m}, 2 \mathrm{H},-\mathrm{CH}$ in 1 and $-\mathrm{CH}$ in 16$), 1.7(\mathrm{~m}, 2 \mathrm{H},-\mathrm{CH}$ in 18 and $-\mathrm{CH}$ in 2), $1.81\left(\mathrm{~s}, 3 \mathrm{H},-\mathrm{CH}_{3}\right.$ in 30$), 1.82(\mathrm{~m}, 1 \mathrm{H},-\mathrm{CH}$ in 2$), 1.85(\mathrm{~m}, 1 \mathrm{H},-\mathrm{CH}$ in 15), $1.96(\mathrm{~m}, 1 \mathrm{H},-\mathrm{CH}$ in 12$), 2.16(\mathrm{~m}, 1 \mathrm{H},-\mathrm{CH}$ in 22$), 2.27(\mathrm{~m}, 1 \mathrm{H}$, $-\mathrm{CH}$ in 21$), 2.47(\mathrm{~m}, 1 \mathrm{H},-\mathrm{CH}$ in 16$), 2.94\left(\mathrm{~d}, 1 \mathrm{H},-\mathrm{CH}\right.$ in $2^{\prime}$, $J=15.5 \mathrm{~Hz}$ ), $3.00\left(\mathrm{~d}, 1 \mathrm{H},-\mathrm{CH}\right.$ in $\left.2^{\prime}, J=15.5 \mathrm{~Hz}\right), 3.01(\mathrm{~m}, 1 \mathrm{H},-\mathrm{CH}$ in $\left.2^{\prime \prime}\right), 3.07(\mathrm{~m}, 1 \mathrm{H},-\mathrm{CH}$ in 13$), 3.67(\mathrm{~m}, 1 \mathrm{H},-\mathrm{CH}$ in 19$), 3.9(\mathrm{~m}, 1 \mathrm{H},-$ $\mathrm{CH}_{2}$ in $\left.1^{\prime \prime}\right), 4.03\left(\mathrm{~m}, 1 \mathrm{H},-\mathrm{CH}_{2}\right.$ in $\left.1^{\prime \prime}\right) 4.79(\mathrm{~m}, 2 \mathrm{H},-\mathrm{CH}$ in 3 and $-\mathrm{CH}$ in-29), $4.97(\mathrm{~s}, 1 \mathrm{H},-\mathrm{CH}$ in 29$), 8.33(\mathrm{t}, 1 \mathrm{H},-\mathrm{NH}-\mathrm{CO}-, J=7 \mathrm{~Hz}) .{ }^{13} \mathrm{C}$ NMR (400 MHz, $\left.\mathrm{C}_{5} \mathrm{D}_{5} \mathrm{~N}\right): \delta 15.2$ (C27); 16.7 (C25); 16.9 (C26); 17.4 (C24); 18.9 (C6); 20 (C30); 21.7 (C11); 24.6 (C2); 26.6 (C12); 26.7 (C5'); 28.6 (C23); 30.3 (C15); 31.8 (C21); 34 (C16); 35 (C7); 35.7 (C2 $\left.{ }^{\prime \prime}\right)$; 36.7 (C1"); 37.7 (C10); 38.2 (C13); 38.5 (C4); 39 (C1); 39.1 (C22); 41.3 (C3'); 41.6 (C8); 43.2 (C14); 45.7 (C2'); 47.7 (C19); 51.1 (C18); 51.2 (C9); 56.1(C5); 56.3 (C17); 81.4 (C3); 110.2 (C29); 152.2 (C20); $172\left(\mathrm{C1}^{\prime}\right) ; 175.4\left(\mathrm{C6}^{\prime \prime}\right) ; 177.2$ (C28); 179.8 (C4'). Anal. $\left(\mathrm{C}_{39} \mathrm{H}_{61} \mathrm{NO}_{7} \cdot 0.5 \mathrm{H}_{2} \mathrm{O}\right) \mathrm{C}, \mathrm{H}, \mathrm{N}$.
5.1.4.3. 4-(\{28-[1,1-dimethylethyl-(2-aminoethyl)carbamate]-28oxolup-20,29-en-3 $\beta$-yl\}oxy)-2,2-dimethyl-4-oxobutanoic acid (14). $R_{f}$ : 0.25 dichloromethane/methanol/acetic acid (10/0.2/0.01); Yield $82 \%$ (190 mg); ${ }^{1} \mathrm{H}$ NMR (300 MHz, $\left.\mathrm{CDCl}_{3}\right): \delta 0.72(\mathrm{~m}, 1 \mathrm{H},-\mathrm{CH}$ in 5$)$, $0.77\left(\mathrm{~s}, 3 \mathrm{H},-\mathrm{CH}_{3}\right), 0.78\left(\mathrm{~s}, 3 \mathrm{H},-\mathrm{CH}_{3}\right), 0.79\left(\mathrm{~s}, 3 \mathrm{H},-\mathrm{CH}_{3}\right), 0.89(\mathrm{~s}, 3 \mathrm{H}$, $\left.-\mathrm{CH}_{3}\right), 0.92\left(\mathrm{~s}, 3 \mathrm{H},-\mathrm{CH}_{3}\right), 1.10(\mathrm{~m}, 1 \mathrm{H}), 1.26(\mathrm{~s}, 6 \mathrm{H}), 1.27-1.40(\mathrm{~m}$, $6 \mathrm{H}), 1.42(\mathrm{~s}, 9 \mathrm{H}, t-\mathrm{Bu}), 1.42-1.63(\mathrm{~m}, 7 \mathrm{H}), 1.69\left(\mathrm{~s}, 3 \mathrm{H},-\mathrm{CH}_{3}\right), 1.72(\mathrm{~m}$, $2 \mathrm{H}), 1.99(\mathrm{~m}, 2 \mathrm{H}), 2.46(\mathrm{~m}, 1 \mathrm{H}), 2.57(\mathrm{~m}, 2 \mathrm{H}), 3.08(\mathrm{~m}, 1 \mathrm{H}), 3.31(\mathrm{~m}$, $9 \mathrm{H}), 4.42(\mathrm{~m}, 1 \mathrm{H}), 4.55(\mathrm{~s}, 1 \mathrm{H},=\mathrm{CH}), 4.69(\mathrm{~s}, 1 \mathrm{H},=\mathrm{CH}), 5.17(\mathrm{~m}, 1 \mathrm{H}$, $-\mathrm{NH}-\mathrm{CO}-), 5.28(\mathrm{~m}, 1 \mathrm{H},-\mathrm{CO}-\mathrm{NH}-)$.

5.1.4.4. $N^{6}$-[(1,1-dimethylethoxy)carbonyl, $N^{2}-[(3 \beta)-3-(3-$ carboxy-3methylbutanoyloxy)-lup-20(29)-en-28-oyl]-L-lysine (15). $R_{f}: 0.31$ $n$-heptane/ethyl acetate/acetic acid (10/10/0.25); Yield $36 \%$ (106 mg); HRMS (ESI) calcd for $\mathrm{C}_{47} \mathrm{H}_{75} \mathrm{~N}_{2} \mathrm{O}_{7}[\mathrm{M}-\mathrm{H}]^{-} 811.5478$ found 811.5476; ${ }^{1} \mathrm{H}$ NMR $\left(400 \mathrm{MHz}, \mathrm{C}_{5} \mathrm{D}_{5} \mathrm{~N}\right): \delta 0.76\left(\mathrm{~s}, 3 \mathrm{H},-\mathrm{CH}_{3}\right.$ in 25$), 0.82$ $(\mathrm{m}, 1 \mathrm{H},-\mathrm{CH}$ in 5$), 0.9(\mathrm{~m}, 1 \mathrm{H},-\mathrm{CH}$ in 1$), 0.96\left(\mathrm{~s}, 3 \mathrm{H},-\mathrm{CH}_{3}\right.$ in 24$), 0.97$ $\left(\mathrm{s}, 3 \mathrm{H},-\mathrm{CH}_{3}\right.$ in 23$), 1.08$ (s, 3H, $-\mathrm{CH}_{3}$ in 27$), 1.09$ (s, $3 \mathrm{H},-\mathrm{CH}_{3}$ in 26$)$, $1.15(\mathrm{~m}, 2 \mathrm{H},-\mathrm{CH}$ in 12 and $-\mathrm{CH}$ in 11$), 1.3(\mathrm{~m}, 1 \mathrm{H},-\mathrm{CH}$ in 9$), 1.32(\mathrm{~m}$, $1 \mathrm{H},-\mathrm{CH}$ in 15$), 1.33(\mathrm{~m}, 1 \mathrm{H},-\mathrm{CH}$ in 11$), 1.36-1.46\left(\mathrm{~m}, 4 \mathrm{H},-\mathrm{CH}_{2}\right.$ in $6,-\mathrm{CH}_{2}$ in 7$), 1.53(\mathrm{~m}, 1 \mathrm{H},-\mathrm{CH}$ in 21$), 1.54(\mathrm{~m}, 1 \mathrm{H},-\mathrm{CH}$ in 22$)$, $1.55-1.59\left(\mathrm{~s}, 3 \mathrm{H},-\mathrm{CH}_{3}\right.$ in $5^{\prime}$ and $\mathrm{s}, 9 \mathrm{H},-\mathrm{NHBoc}$ and $\mathrm{m}, 1 \mathrm{H},-\mathrm{CH}$ in 1$)$, $1.67-1.70(\mathrm{~m}, 2 \mathrm{H},-\mathrm{CH}$ in $2,-\mathrm{CH}$ in 16$), 1.70,1.73(\mathrm{~m}, 1 \mathrm{H},-\mathrm{CH}$ in 18$)$, $1.78(\mathrm{~m}, 1 \mathrm{H},-\mathrm{CH}$ in 2$), 1.78\left(\mathrm{~s}, 3 \mathrm{H},-\mathrm{CH}_{3}\right.$ in 30$), 1.8\left(\mathrm{~m}, 2 \mathrm{H},-\mathrm{CH}_{2 \gamma} \mathrm{Lys}\right)$, $1.83\left(\mathrm{~m}, 1 \mathrm{H},-\mathrm{CH}_{2 \delta} \mathrm{Lys}\right), 1.89(\mathrm{~m}, 1 \mathrm{H},-\mathrm{CH}$ in 15$), 1.95(\mathrm{~m}, 1 \mathrm{H},-\mathrm{CH}$ in 12), $2.06\left(\mathrm{~m}, 1 \mathrm{H},-\mathrm{CH}_{2 \beta}\right.$ Lys $), 2.3\left(\mathrm{~m}, 1 \mathrm{H},-\mathrm{CH}_{2 \beta} \mathrm{Lys}\right), 2.34(\mathrm{~m}, 1 \mathrm{H},-\mathrm{CH}$ in 21$), 2.43(\mathrm{~m}, 1 \mathrm{H},-\mathrm{CH}$ in 22$), 2.58(\mathrm{~m}, 1 \mathrm{H},-\mathrm{CH}$ in 16$), 2.9(\mathrm{~d}, 1 \mathrm{H}$, $-\mathrm{CH}$ in $\left.2^{\prime}, J=15.5 \mathrm{~Hz}\right), 2.98\left(\mathrm{~d}, 1 \mathrm{H},-\mathrm{CH}\right.$ in $\left.2^{\prime}, J=15.5 \mathrm{~Hz}\right), 3.07(\mathrm{~m}, 1 \mathrm{H}$, $-\mathrm{CH}$ in 13$), 3.43\left(\mathrm{~m}, 2 \mathrm{H},-\mathrm{CH}_{2 \varepsilon} \mathrm{Lys}\right), 3.63(\mathrm{~m}, 1 \mathrm{H},-\mathrm{CH}$ in 19$), 4.77$ (s, $1 \mathrm{H},-\mathrm{CH}$ in 29$), 4.78(\mathrm{dd}, 1 \mathrm{H},-\mathrm{CH}$ in $3, J=5 \mathrm{~Hz}$ and $J=11.5 \mathrm{~Hz}), 4.92$ (s, $1 \mathrm{H},-\mathrm{CH}$ in 29), $5.17\left(\mathrm{~m}, 1 \mathrm{H},-\mathrm{CH}_{\alpha}\right.$ Lys), $7.58(\mathrm{~m}, 1 \mathrm{H},-\mathrm{NH}-\mathrm{CO}-\mathrm{O})$, $8.26(\mathrm{~d}, 1 \mathrm{H},-\mathrm{CO}-\mathrm{NH}-\mathrm{J}=8 \mathrm{~Hz}) .{ }^{13} \mathrm{C} \mathrm{NMR}\left(400 \mathrm{MHz}, \mathrm{C}_{5} \mathrm{D}_{5} \mathrm{~N}\right): \delta 15.3$ (C27); 16.7 (C25); 17 (C26); 17.4 (C24); 19 (C6); 20.0 (C30); 21.7 (C11); 24.5 (C $\gamma$ Lys); 24.6 (C2); $26.4\left(\right.$ C5 $\left.^{\prime}\right) ; 26.6$ (C12); 28.6 (C23); 29.1 (3C, Boc); 30.3 (C15); 30.6 (C $\delta$ Lys); 31.9 (C21); 32.4 (C $\beta$ Lys); 34.2 (C16); 35.1 (C7); 37.75 (C10); 38.1 (C13); 38.5 (C4); 38.8 (C22); 39 (C1); 41.3 (C3'); 41.4 (CELys); 41.6 (C8); 43.2 (C14); 45.7 (C2'); 47.7 (C19); 51.1 (C18); 51.2 (C9); 53 (CaLys) 56.1 (C5); 56.5 (C17); 78.4 (COBoc); 81.4 (C3); 110.2 (C29); $152.2(\mathrm{C} 20) ; 172.1\left(\mathrm{C1}^{\prime}\right)$; $176.6\left(\mathrm{C6}^{\prime \prime}\right)$; 177.7 (C28); $179.8\left(\mathrm{C}^{\prime}\right)$. Anal. $\left(\mathrm{C}_{47} \mathrm{H}_{76} \mathrm{~N}_{2} \mathrm{O}_{9} \cdot 2 \mathrm{H}_{2} \mathrm{O}\right) \mathrm{C}, \mathrm{H}, \mathrm{N}$.

\subsubsection{Procedure for synthesis of compound 4-(\{28-[(2-aminoethyl)} amino]-28-oxolup-20,29-en-3 $\beta$-yl\}oxy)-2,2-dimethyl-4-

oxobutanoic acid (16)

tert-Butyldimethylsilyltrifluoromethanesulfonate $\quad\left(t-\mathrm{BuMe}_{2}\right.$ SiOTf, $150 \mu \mathrm{L}, 0.65 \mathrm{mmol}$ ) was added dropwise to a stirred solution under argon of $\mathrm{N}$-tert-Boc derivatives $14(0.19 \mathrm{mg}, 0.26 \mathrm{mmol})$ and 2,6-lutidine ( $91 \mu \mathrm{L}, 0.78 \mathrm{mmol})$ in dry $\mathrm{CH}_{2} \mathrm{Cl}_{2}(1 \mathrm{~mL})$. The reaction mixture was stirred $30 \mathrm{~min}$, quenched with saturated aqueous ammonium chloride solution $(2 \mathrm{~mL})$. The mixture was diluted with $\mathrm{CH}_{2} \mathrm{Cl}_{2}$ (5 mL), the organic layer was washed with water, brine and dried over $\mathrm{MgSO}_{4}$. The solvent was concentrated under vacuum and the residue was used in the next step without purification. Tetrabutylammonium fluoride ( $260 \mu \mathrm{L}, 1 \mathrm{M}$ solution in THF, $0.26 \mathrm{mmol})$ was added to a stirred solution of the $\mathrm{N}$-(tert-butyldimethylsilyloxycarbonyl) derivatives in dry THF $(0.5 \mathrm{~mL})$ at room temperature. The reaction mixture was stirred for $1 \mathrm{~h}$, quenched with saturated aqueous ammonium chloride solution $(2 \mathrm{~mL})$. The resulting precipitate was collected, washed with water and dried over vacuum to yield the corresponding compound $\mathbf{1 6}$ (Refer to Supporting data). Yield: 26\% (45 mg); HRMS (ESI) calcd for $\mathrm{C}_{38} \mathrm{H}_{61} \mathrm{~N}_{2} \mathrm{O}_{5}[\mathrm{M}-\mathrm{H}]^{-}$ 625.4586 found $625.4569 ;{ }^{1} \mathrm{H} \mathrm{NMR}\left(400 \mathrm{MHz}, \mathrm{C}_{5} \mathrm{D}_{5} \mathrm{~N}\right): \delta 0.75(\mathrm{~s}, 3 \mathrm{H}$, $-\mathrm{CH}_{3}$ in 25$), 0.77(\mathrm{~m}, 1 \mathrm{H},-\mathrm{CH}$ in 5$), 0.86(\mathrm{~m}, 1 \mathrm{H},-\mathrm{CH}$ in 1$), 0.93(\mathrm{~s}$, $3 \mathrm{H},-\mathrm{CH}_{3}$ in 24$), 0.97\left(\mathrm{~s}, 3 \mathrm{H},-\mathrm{CH}_{3}\right.$ in 23$), 1.03\left(\mathrm{~s}, 3 \mathrm{H},-\mathrm{CH}_{3}\right.$ in 27$), 1.03$ $\left(\mathrm{s}, 3 \mathrm{H},-\mathrm{CH}_{3}\right.$ in 26$), 1.12(\mathrm{~m}, 1 \mathrm{H},-\mathrm{CH}$ in 12$), 1.13(\mathrm{~m}, 1 \mathrm{H},-\mathrm{CH}$ in 11$)$, 
$1.17(\mathrm{~m}, 1 \mathrm{H},-\mathrm{CH}$ in 15$), 1.30(\mathrm{~m}, 2 \mathrm{H},-\mathrm{CH}$ in $9,-\mathrm{CH}$ in 11$), 1.30-1.40$ $\left(\mathrm{m}, 4 \mathrm{H},-\mathrm{CH}_{2}\right.$ in $6,-\mathrm{CH}_{2}$ in 7$), 1.48(\mathrm{~m}, 1 \mathrm{H},-\mathrm{CH}$ in 21$), 1.54(\mathrm{~m}, 1 \mathrm{H}$, $-\mathrm{CH}$ in 1$), 1.55\left(\mathrm{~s}, 3 \mathrm{H},-\mathrm{CH}_{3}\right.$ in $\left.5^{\prime}\right), 1.55(\mathrm{~m}, 1 \mathrm{H},-\mathrm{CH}$ in 22$), 1.64-1.67$ $(\mathrm{m}, 2 \mathrm{H},-\mathrm{CH}$ in $2,-\mathrm{CH}$ in 16$), 1.70(\mathrm{~m}, 2 \mathrm{H},-\mathrm{CH}$ in $15,-\mathrm{CH}$ in 18$), 1.77$ $(\mathrm{m}, 1 \mathrm{H},-\mathrm{CH}$ in 2$), 1.77\left(\mathrm{~s}, 3 \mathrm{H},-\mathrm{CH}_{3}\right.$ in 30$), 1.92(\mathrm{~m}, 1 \mathrm{H},-\mathrm{CH}$ in 12$)$, $2.14(\mathrm{~m}, 1 \mathrm{H},-\mathrm{CH}$ in 21$), 2.25(\mathrm{~m}, 1 \mathrm{H},-\mathrm{CH}$ in 22$), 2.67 \mathrm{~m}, 1 \mathrm{H},-\mathrm{CH}$ in 16), $2.90\left(\mathrm{~d}, 1 \mathrm{H},-\mathrm{CH}\right.$ in $\left.2^{\prime}, J=15.5 \mathrm{~Hz}\right), 2.96\left(\mathrm{~d}, 1 \mathrm{H},-\mathrm{CH}\right.$ in $2^{\prime}$, $J=15.5 \mathrm{~Hz}), 3.03(\mathrm{~m}, 1 \mathrm{H},-\mathrm{CH}$ in 13$), 3.28\left(\mathrm{~m}, 2 \mathrm{H},-\mathrm{CH}_{2}\right.$ in $\left.2^{\prime \prime}\right), 3.61$ ( $\mathrm{m}, 1 \mathrm{H},-\mathrm{CH}$ in 19$), 3.87-3.81\left(\mathrm{~m}, 2 \mathrm{H},-\mathrm{CH}_{2}\right.$ in $\left.1^{\prime \prime}\right), 4.75(\mathrm{~s}, 1 \mathrm{H},-\mathrm{CH}$ in 29), $4.77(\mathrm{~d}, 1 \mathrm{H},-\mathrm{CH}$ in $3, J=5 \mathrm{~Hz}), 4.93(\mathrm{~s}, 1 \mathrm{H},-\mathrm{CH}$ in 29$), 8.74(\mathrm{~m}$, $1 \mathrm{H},-\mathrm{NH}-\mathrm{CO}-) .{ }^{13} \mathrm{C}$ NMR (400 MHz, $\left.\mathrm{C}_{5} \mathrm{D}_{5} \mathrm{~N}\right): \delta 15.2$ (C27); 16.7 (C25); 16.9 (C26); 17.4 (C24); 19 (C6); 20.0 (C30); 21.6 (C11); 24.6 (C2); 26.5 (C12); 26.7 (C5'); 28.5 (C23); 30.3 (C15); 31.8 (C21); 34.0 (C16); 35.0 (C7); 37.7 (C10); 38.1 (C13); 38.5 (C4); 39.0 (C22); 39.1 (C1); 41.0 (C1"); $41.4\left(\mathrm{C}^{\prime}\right) ; 41.5$ (C8); $42.2\left(\mathrm{C}^{\prime \prime}\right) ; 43.1$ (C14); 45.7 (C2'); 47.7 (C19); 51.2 (C18); 51.3 (C9); 56.1 (C5); 56.5 (C17); 81.3 (C3); 110.2 (C29); 152.2 (C20); $172.1\left(\mathrm{C1}^{\prime}\right) ; 177.7$ (C28); 179.9 (C4'). Anal. $\left(\mathrm{C}_{38} \mathrm{H}_{62} \mathrm{~N}_{2} \mathrm{O}_{5} \cdot 3 \mathrm{H}_{2} \mathrm{O}\right) \mathrm{C}, \mathrm{H}, \mathrm{N}$.

5.1.6. Procedure for synthesis of compound $N^{2}-[(3 \beta)-3-(3-$ carboxy3-methylbutanoyloxy)lup-20(29)-en-28-oyl]-L-lysine (17)

The $N$-Boc protection of product 15 was cleaved with $6 \mathrm{M} \mathrm{HCl}$ in THF for $1 \mathrm{~h}$. Compound $\mathbf{1 7}$ was obtained after purification by flash chromatography. Yield: 45\% (20 mg); HRMS (ESI) calcd for $\mathrm{C}_{42} \mathrm{H}_{67} \mathrm{~N}_{2} \mathrm{O}_{7}[\mathrm{M}-\mathrm{H}]^{-} 711.4954$ found $711.4960 ;{ }^{1} \mathrm{H} \mathrm{NMR}(400 \mathrm{MHz}$, $\left.\mathrm{CD}_{3} \mathrm{OD}\right): \delta 0.82(\mathrm{~m}, 1 \mathrm{H},-\mathrm{CH}$ in 5$), 0.85\left(\mathrm{~s}, 3 \mathrm{H},-\mathrm{CH}_{3}\right.$ in 24$), 0.87(\mathrm{~s}$, $3 \mathrm{H},-\mathrm{CH}_{3}$ in 23), $0.92\left(\mathrm{~s}, 3 \mathrm{H},-\mathrm{CH}_{3}\right.$ in 25$), 0.96\left(\mathrm{~s}, 3 \mathrm{H},-\mathrm{CH}_{3}\right.$ in 26$)$, $0.99(\mathrm{~m}, 1 \mathrm{H},-\mathrm{CH}$ in 1$), 1.01\left(\mathrm{~s}, 3 \mathrm{H},-\mathrm{CH}_{3}\right.$ in 27$), 1.04(\mathrm{~m}, 1 \mathrm{H},-\mathrm{CH}$ in 12), $1.18(\mathrm{~m}, 1 \mathrm{H},-\mathrm{CH}$ in 15$), 1.25\left(\mathrm{~s}, 3 \mathrm{H},-\mathrm{CH}_{3}\right.$ in $\left.5^{\prime}\right), 1.26(\mathrm{~m}, 1 \mathrm{H},-\mathrm{CH}$ in 11$), 1.35(\mathrm{~m}, 1 \mathrm{H},-\mathrm{CH}$ in 21$), 1.36(\mathrm{~m}, 1 \mathrm{H},-\mathrm{CH}$ in 9$), 1.38-1.52(\mathrm{~m}$, $9 \mathrm{H},-\mathrm{CH}_{2}$ in $6,-\mathrm{CH}_{2}$ in $7,-\mathrm{CH}$ in $11,-\mathrm{CH}$ in $15,-\mathrm{CH}$ in $22,-\mathrm{CH}_{2}$ in $\left.3^{\prime \prime}\right), 1.56(\mathrm{~m}, 1 \mathrm{H},-\mathrm{CH}$ in 16$), 1.6(\mathrm{~m}, 1 \mathrm{H},-\mathrm{CH}$ in 2$), 1.64(\mathrm{~m}, 1 \mathrm{H},-\mathrm{CH}$ in 18$), 1.68(\mathrm{~m}, 1 \mathrm{H},-\mathrm{CH}$ in 2$), 1.7\left(\mathrm{~m}, 6 \mathrm{H},-\mathrm{CH}_{3}\right.$ in $30,-\mathrm{CH}$ in $12,2 \mathrm{H}$, $-\mathrm{CH}_{2}$ in $\left.4^{\prime \prime}\right), 1.72(\mathrm{~m}, 1 \mathrm{H},-\mathrm{CH}$ in 1$), 1.75\left(\mathrm{~m}, 1 \mathrm{H},-\mathrm{CH}\right.$ in $\left.2^{\prime \prime}\right), 1.89(\mathrm{~m}$, $1 \mathrm{H},-\mathrm{CH}$ in $\left.2^{\prime \prime}\right), 1.9(\mathrm{~m}, 1 \mathrm{H},-\mathrm{CH}$ in 21$), 1.93(\mathrm{~m}, 1 \mathrm{H},-\mathrm{CH}$ in 22$), 2.17$ $(\mathrm{m}, 1 \mathrm{H},-\mathrm{CH}$ in 16$), 2.53(\mathrm{~m}, 1 \mathrm{H},-\mathrm{CH}$ in 13$), 2.55\left(\mathrm{~d}, 1 \mathrm{H},-\mathrm{CH}\right.$ in $2^{\prime}$, $J=15.5 \mathrm{~Hz}), 2.62\left(\mathrm{~d}, 1 \mathrm{H},-\mathrm{CH}\right.$ in $\left.2^{\prime}, J=15.5 \mathrm{~Hz}\right), 2.90(\mathrm{t}, 2 \mathrm{H},-\mathrm{CH}$ in $\left.5^{\prime \prime}, J=8 \mathrm{~Hz}\right), 3.06(\mathrm{~m}, 1 \mathrm{H},-\mathrm{CH}$ in 19$), 4.3\left(\mathrm{~m}, 1 \mathrm{H},-\mathrm{CH}\right.$ in $\left.1^{\prime \prime}\right), 4.44$ (dd, $1 \mathrm{H},-\mathrm{CH}$ in $3, J=5 \mathrm{~Hz}$ and $J=10 \mathrm{~Hz}), 4.57(\mathrm{~s}, 1 \mathrm{H},-\mathrm{CH}$ in 29$), 4.7$ (s, $1 \mathrm{H},-\mathrm{CH}$ in 29$), 7.1(\mathrm{~m}, 1 \mathrm{H},-\mathrm{NH}-\mathrm{CO}-) .{ }^{13} \mathrm{C}$ NMR $(400 \mathrm{MHz}$, $\mathrm{CD}_{3} \mathrm{OD}$ ): $\delta 15.2$ (C27); 17 (C25); 17.1 (C26); 17.2 (C24); 19.4 (C6); 19.8 (C30); 22.3 (C11); 24.05 (C3"); 24.8 (C2); 26.2 (C5'); 27.2 (C12); 28.2 (C4"); 28.7 (C23); 30.9 (C15); 32.1 (C21); 32.7 (C2" ); 34.4 (C16); 35.7 (C7); 38.4 (C10); 39 (C4); 39.2 (C13); 39.3 (C22); 39.8 (C1); 40.7 (C5'); 41.5 (C3'); 42.2 (C8); 43.7 (C14); 45.8 (C2'); 48.3 (C19); 51.4 (C18); 52.1 (C9); 54 (C1"); 57 (C5); 57.4 (C17); 82.8 (C3); 110.2 (C29); 152.4 (C20); $173.1\left(\mathrm{C}^{\prime}\right)$; $177.3\left(\mathrm{C6}^{\prime \prime}\right) ; 178.9(\mathrm{C} 28) ; 180.8\left(\mathrm{C4}^{\prime}\right)$. Anal. $\left(\mathrm{C}_{42} \mathrm{H}_{68} \mathrm{~N}_{2} \mathrm{O}_{7} \cdot 2 \mathrm{H}_{2} \mathrm{O}\right) \mathrm{C}, \mathrm{H}, \mathrm{N}$.

\subsection{HPLC analysis}

HPLC analysis were conducted using a Shimadzu LC-10ADvp with a Nucleodur $4.6 \mathrm{~mm} \times 250 \mathrm{~mm} \mathrm{C} 18$ HTec $5 \mu \mathrm{m}$ column and a Shimadzu SPD-M10Avp detector at $210 \mathrm{~nm}$ wavelength. The solvent system used was $\mathrm{MeOH}(0.1 \% \mathrm{TFA})$ : water $(0.1 \% \mathrm{TFA})=90: 10$. The isocratic HPLC mode was used and the flow rate was set to $1 \mathrm{~mL} / \mathrm{min}$.

\section{3. $N M R$}

${ }^{1} \mathrm{H}$ NMR, ${ }^{13} \mathrm{C}$ NMR, DEPT135, DQF-COSY, TOCSY, HSQC and HMBC spectra of compounds $\mathbf{2 , 1 2 , 1 3 , 1 5 , 1 6}$ and 17 (Fig. 1) were recorded on a Bruker AVANCE 400 NMR spectrometer operating at $400.13 \mathrm{MHz}$ (SF) for ${ }^{1} \mathrm{H}$ and $100.623 \mathrm{MHz}$ (SF) for ${ }^{13} \mathrm{C}$ with a $5 \mathrm{~mm}$ inverse probe at room temperature. The concentration of the different compounds was $10 \mathrm{mM}$ in $0.5 \mathrm{~mL} \mathrm{C}_{5} \mathrm{D}_{5} \mathrm{~N}$, in $5 \mathrm{~mm}$ NMR tubes. All chemical shifts are given in ppm (Fig. 3) and (Tables 1 and 2 and Figures S1 to S5 in supplementary data). The NMR spectra were registered with a spectral width of $4084.97 \mathrm{~Hz}$ and 22,522.52 $\mathrm{Hz}$ for the ${ }^{1} \mathrm{H}$ and ${ }^{13} \mathrm{C}$ dimensions respectively. WALTZ $[60,61]$ pulse sequence was used for ${ }^{1} \mathrm{H}$ decoupling. The DEPT135 experiment (Distortionless Enhancement by Polarization Transfer) using polarization transfer from proton to other nuclei via one covalent bond allowed the determination of the $\mathrm{CH}_{n}$ multiplicity. All 2D experiments were performed using standard pulse sequences with the Bruker software program XWIN-NMR vs. 3.0. DQF-COSY and TOCSY spectra were recorded with 2048 points in the $F 2$ dimension and 512 increments in the $F 1$ dimension. Each increment was obtained with 40 scans, a spectral width of $4084.97 \mathrm{~Hz}$, a recycling delay of $2 \mathrm{~s}$ and a mixing time of $80 \mathrm{~ms}$ were used for the TOCSY experiments. The HSQC spectra were obtained with the one-bond ${ }^{1} \mathrm{H}-{ }^{13} \mathrm{C}$ coupling constant set to $145 \mathrm{~Hz}$, a GARP ${ }^{13} \mathrm{C}$ decoupling WALTZ [60,62], 2048 points in the $F 2$ dimension and 256 increments in the $F 1$ dimension, with a relaxation delay of $2 \mathrm{~s}$. The spectral width was set to $10,964.91 \mathrm{~Hz}$ and $4084.97 \mathrm{~Hz}$ in the $F 2$ and $F 1$ dimensions respectively. The $2 \mathrm{D}\left({ }^{1} \mathrm{H}-{ }^{13} \mathrm{C}\right)$-HMBC experiments were performed with 40 scans for each of $256 \mathrm{~F} 1$ increments and 2048 data points in F2. Spectral widths of $4084.97 \mathrm{~Hz}$ and 22,522.52 $\mathrm{Hz}$ were used in the ${ }^{1} \mathrm{H}$ and ${ }^{13} \mathrm{C}$ dimensions respectively.

2D NMR spectra demonstrating the interaction between the CASP1-NC junction and compound $\mathbf{1 6}$ were recorded at $293 \mathrm{~K}$ on a $600 \mathrm{MHz}$ Bruker Avance spectrometer equipped with a $5 \mathrm{~mm}$ triple resonance inverse probe and a XYZ gradient unit. $2 \mathrm{D}{ }^{1} \mathrm{H}-{ }^{1} \mathrm{H}$ NOESY spectra were recorded for the peptide CA-SP1-NC $(250 \mu \mathrm{M})$ in the absence and presence of compound $16(550 \mu \mathrm{M})$ and superimposed, at a pH of 3.8, in H2O/TFE (70/30) mixture to prevent aggregation, DMSO- $d_{6}(1 \%)$ and a spectral width of $5296.6 \mathrm{~Hz}$ in both dimensions. Water suppression was achieved by using excitation sculpting with a $2 \mathrm{~ms}$ selective Gaussian pulse at the water signal frequency and a $250 \mathrm{~ms}$ NOE mixing time (Fig. 4B).

\subsection{HIV-1 infection inhibition assays}

Infectivity of HIV-1 particles produced in the presence of inhibitors was carried out using MAGIC-5B indicator cells, which stably express the $\beta$-galactosidase reporter gene cloned downstream of the HIV- 1 LTR promoter. Cells were plated at $8 \times 10^{4}$ cells per well, in 24-well plates and exposed to virus-containing supernatants produced by transfection of the HIV-1 molecular clone (pNL-4.3) in 293T cells maintained in the presence or absence of compounds 1, 2, 12, 13, 15, 16 and 17. Forty-eight hours postinfection, viral infectivity was monitored by quantification of onitrophenyl $\beta$-D-galactopyranoside hydrolysis from cell lysates (kit). $\beta$-galactosidase activity was normalized according to the total protein content in the cell lysate. The control wells containing the virus and cells only (no virus or drug) were also prepared. The $50 \%$ infection inhibition $\left(\mathrm{IC}_{50}\right)$ was defined as the concentration of the compound that reduced the HIV-1 infection level by $50 \%$ compared to the untreated controls (Table 3 ).

\subsection{Electron microscopy analysis}

293T cells were transfected with HIV-1 molecular clones (pNL-43 ) using the JetPei transfection reagent (QBiogen) and maintained in the presence or absence of 1, 2, 12, 13, 15, 16 and $\mathbf{1 7}(5 \mu \mathrm{g} / \mathrm{ml})$. Two days after transfection, the cells were processed for thin-layer electron microscopy as follows: the cells were fixed in situ with $2.5 \%$ glutaraldehyde in cacodylate buffer $(\mathrm{pH} 7.4)$ for $60 \mathrm{~min}$ at $4{ }^{\circ} \mathrm{C}$. They were then post-fixed with $2 \%$ osmium tetroxide, washed in cacodylate buffer containing $0.5 \%$ tanic acid, and embedded in epon (Embed-812, Electron Microscopy Sciences Inc.). The sections were 
counterstained with uranyl acetate and lead citrate and examined with an Hitachi H7100 transmission electron microscope.

\subsection{Cytotoxicity}

The cellular toxicity of the different compounds was evaluated using the MTT assays (CellTiter 96 aqueous one solution proliferation assay system, Promega). The $50 \%$ cytotoxic concentration $\left(\mathrm{CC}_{50}\right)$ was defined as the concentration of the compounds that reduced the cell viability by $50 \%$ compared to that for the untreated controls. The selectivity index (SI) was defined as the ratio $\mathrm{CC}_{50}$ : $\mathrm{IC}_{50}$ (Table 3 ).

\subsection{HIV-1 maturation inhibition assay}

Viruses were produced by transfection of HIV-1 molecular clones (pNL-4-3) in 293T cells maintained in the presence or absence of compounds 1, 2, 12, 13, 15, 16 and 17 in DMSO using the JetPei transfection reagent (QBiogen). Two days after the transfection, virus-containing supernatants were concentrated by ultracentrifugation through a layer of $20 \%$ sucrose at $25,000 \mathrm{rpm}$ for $2 \mathrm{~h} 30 \mathrm{~min}$. Viral pellets were then suspended in RIPA lysis buffer [10 mM Tris- $\mathrm{HCl}$ (pH 7.4), $1 \mathrm{mM}$ EDTA, $100 \mathrm{mM} \mathrm{NaCl}, 1 \%$ Triton $\mathrm{X}-100,0.1 \%$ SDS, $0.25 \%$ sodium deoxycholate, $0.2 \%$ phenylmethylsulfonyl fluoride (PMSF)]. Viral proteins were loaded on a $12.5 \%$ SDS-PAGE gel. The proteins transferred to the PVDF membrane (Millipore) were revealed using a goat anti-HIV CAp24 serum (AbD Serotec). Secondary antibody conjugated to horseradish peroxidase was revealed by enhanced chemiluminescent detection (Pierce Biotechnology, Inc).

\section{Acknowledgments}

We wish to thank the ANRS (Agence Nationale de Recherche sur le SIDA et les hépatites virales) and Sidaction (Ensemble contre le SIDA) for their financial support.

\section{Appendix A. Supplementary data}

Supplementary data related to this article can be found at http:// dx.doi.org/10.1016/j.ejmech.2013.01.013.

\section{References}

[1] C.J. Achenbach, K.M. Darin, R.L. Murphy, C. Katlama, Future Virol. 6 (2011) $157-177$.

[2] S. Ibe, W. Sugiura, Future Microbiol. 6 (2011) 295-315.

[3] C. Liao, C. Marchand, T.R. Burke Jr., Y. Pommier, M.C. Nicklaus, Future Med. Chem. 2 (2010) 1107-1122.

[4] M. Metifiot, C. Marchand, K. Maddali, Y. Pommier, Viruses 2 (2010) 1347-1366

[5] L. Griffin, P. Annaert, K.L. Brouwer, J. Pharm. Sci. 100 (2011) 3636-3654.

[6] C.T. Wang, E. Barklis, J. Virol. 67 (1993) 4264-4273.

[7] K. Wiegers, G. Rutter, H. Kottler, U. Tessmer, H. Hohenberg, H.G. Krausslich, J. Virol. 72 (1998) 2846-2854.

[8] T. Dorfman, A. Bukovsky, A. Ohagen, S. Hoglund, H.G. Gottlinger, J. Virol. 68 (1994) 8180-8187.

[9] H.G. Krausslich, M. Facke, A.M. Heuser, J. Konvalinka, H. Zentgraf, J. Virol. 69 (1995) 3407-3419.

[10] H.G. Gottlinger, J.G. Sodroski, W.A. Haseltine, Proc. Natl. Acad. Sci. U. S. A. 86 (1989) 5781-5785.

[11] A. von Poblotzki, R. Wagner, M. Niedrig, G. Wanner, H. Wolf, S. Modrow Virology 193 (1993) 981-985.

[12] M.A. Accola, S. Hoglund, H.G. Gottlinger, J. Virol. 72 (1998) 2072-2078.

[13] M.A. Accola, B. Strack, H.G. Gottlinger, J. Virol. 74 (2000) 5395-5402.

[14] A. Ono, D. Demirov, E.O. Freed, J. Virol. 74 (2000) 5142-5150.

[15] J. Sarek, J. Klinot, P. Dzubak, E. Klinotova, V. Noskova, V. Krecek, G. Korinkova, J.O. Thomson, A. Janost'akova, S. Wang, S. Parsons, P.M. Fischer, N.Z. Zhelev, M. Hajduch, J. Med. Chem. 46 (2003) 5402-5415.

[16] Y. Morikawa, D.J. Hockley, M.V. Nermut, I.M. Jones, J. Virol. 74 (2000) 16-23.

[17] N. Morellet, S. Druillennec, C. Lenoir, S. Bouaziz, B.P. Roques, Protein Sci. 14 (2005) 375-386.
[18] E.R. Wright, J.B. Schooler, H.J. Ding, C. Kieffer, C. Fillmore, W.I. Sundquist, G.J. Jensen, EMBO J. 26 (2007) 2218-2226.

[19] S.A. Datta, L.G. Temeselew, R.M. Crist, F. Soheilian, A. Kamata, J. Mirro, D. Harvin, K. Nagashima, R.E. Cachau, A. Rein, J. Virol. 85 (2011) 4111-4121.

[20] Y. Kashiwada, F. Hashimoto, L.M. Cosentino, C.H. Chen, P.E. Garrett, K.H. Lee, J. Med. Chem. 39 (1996) 1016-1017.

[21] F. Soler, C. Poujade, M. Evers, J.C. Carry, Y. Henin, A. Bousseau, T. Huet, R. Pauwels, E. De Clercq, J.F. Mayaux, J.B. Le Pecq, N. Dereu, J. Med. Chem. 39 (1996) 1069-1083.

[22] M. Evers, C. Poujade, F. Soler, Y. Ribeill, C. James, Y. Lelievre, J.C. Gueguen, D. Reisdorf, I. Morize, R. Pauwels, E. De Clercq, Y. Henin, A. Bousseau, J.F. Mayaux, J.B. Le Pecq, N. Dereu, J. Med. Chem. 39 (1996) 1056-1068.

[23] F. Hashimoto, Y. Kashiwada, L.M. Cosentino, C.H. Chen, P.E. Garrett, K.H. Lee, Bioorg. Med. Chem. 5 (1997) 2133-2143.

[24] J. Zhou, X. Yuan, D. Dismuke, B.M. Forshey, C. Lundquist, K.H. Lee, C. Aiken, C.H. Chen, J. Virol. 78 (2004) 922-929.

[25] C. Aiken, C.H. Chen, Trends Mol. Med. 11 (2005) 31-36.

[26] F. Li, R. Goila-Gaur, K. Salzwedel, N.R. Kilgore, M. Reddick, C. Matallana, A. Castillo, D. Zoumplis, D.E. Martin, J.M. Orenstein, G.P. Allaway, E.O. Freed, C.T. Wild, Proc. Natl. Acad. Sci. U. S. A. 100 (2003) 13555-13560.

[27] P.W. Keller, C.S. Adamson, J.B. Heymann, E.O. Freed, A.C. Steven, J. Virol. 85 (2011) 1420-1428.

[28] K. Waki, S.R. Durell, F. Soheilian, K. Nagashima, S.L. Butler, E.O. Freed, PLoS Pathog. 8 (2012) e1002997.

[29] L. Huang, P. Ho, K.H. Lee, C.H. Chen, Bioorg. Med. Chem. 14 (2006) 2279-2289.

[30] W. Lai, L. Huang, P. Ho, Z. Li, D. Montefiori, C.H. Chen, Antimicrob. Agents Chemother. 52 (2008) 128-136.

[31] K. Qian, I.D. Bori, C.H. Chen, L. Huang, K.H. Lee, J. Med. Chem. 55 (2012) 81288136.

[32] K. Qian, D. Yu, C.H. Chen, L. Huang, S.L. Morris-Natschke, T.J. Nitz, K. Salzwedel, M. Reddick, G.P. Allaway, K.H. Lee, J. Med. Chem. 52 (2009) 3248-3258.

[33] D. Gerrish, I.C. Kim, D.V. Kumar, H. Austin, J.E. Garrus, V. Baichwal, M. Saunders, R.S. McKinnon, M.B. Anderson, R. Carlson, E. Arranz-Plaza, K.M. Yager, Bioorg. Med. Chem. Lett. 18 (2008) 6377-6380.

[34] I.C. Sun, J.K. Shen, H.K. Wang, L.M. Cosentino, K.H. Lee, Bioorg. Med. Chem. Lett. 8 (1998) 1267-1272.

[35] I.C. Sun, H.K. Wang, Y. Kashiwada, J.K. Shen, L.M. Cosentino, C.H. Chen, L.M. Yang, K.H. Lee, J. Med. Chem. 41 (1998) 4648-4657.

[36] D. Yu, C.T. Wild, D.E. Martin, S.L. Morris-Natschke, C.H. Chen, G.P. Allaway, K.H. Lee, Expert Opin. Investig. Drugs 14 (2005) 681-693.

[37] G. Gonzalez, S. DaFonseca, E. Errazuriz, P. Coric, F. Souquet, S. Turcaud, P. Boulanger, S. Bouaziz, S.S. Hong, PLoS One 6 (2011) e27234.

[38] J. Zhou, L. Huang, D.L. Hachey, C.H. Chen, C. Aiken, J. Biol. Chem. 280 (2005) 42149-42155.

[39] D.E. Martin, R. Blum, J. Wilton, J. Doto, H. Galbraith, G.L. Burgess, P.C. Smith, C. Ballow, Antimicrob. Agents Chemother. 51 (2007) 3063-3066.

[40] P.F. Smith, A. Ogundele, A. Forrest, J. Wilton, K. Salzwedel, J. Doto, G.P. Allaway, D.E. Martin, Antimicrob. Agents Chemother. 51 (2007) 3574-3581.

[41] S. DaFonseca, A. Blommaert, P. Coric, S.S. Hong, S. Bouaziz, P. Boulanger, Antivir. Ther. 12 (2007) 1185-1203.

[42] S. Dafonseca, P. Coric, B. Gay, S.S. Hong, S. Bouaziz, P. Boulanger, Virol. J. 5 (2008) 162.

[43] I.C. Sun, C.H. Chen, Y. Kashiwada, J.H. Wu, H.K. Wang, K.H. Lee, J. Med. Chem. 45 (2002) 4271-4275.

[44] Z. Dang, K. Qian, P. Ho, L. Zhu, K.H. Lee, L. Huang, C.H. Chen, Bioorg. Med. Chem. Lett. 22 (2012) 5190-5194.

[45] P. Lan, W.N. Chen, Z.J. Huang, P.H. Sun, W.M. Chen, J. Mol. Model. 17 (2011) 1643-1659.

[46] M. Sakaitani, Y. Ohfune, J. Org. Chem. 55 (1990) 870-876.

[47] H.J. Jeong, H.B. Chai, S.Y. Park, D.S. Kim, Bioorg. Med. Chem. Lett. 9 (1999) 1201-1204.

[48] C. Peng, G. Bodenhausen, S. Qiu, H.H.S. Fong, N.R. Farnsworth, S. Yuan, C. Zheng, Magn. Reson. Chem. 36 (1998) 267-278.

[49] R.H. Cichewicz, S.A. Kouzi, Med. Res. Rev. 24 (2004) 90-114.

[50] K. Qian, R.Y. Kuo, C.H. Chen, L. Huang, S.L. Morris-Natschke, K.H. Lee, J. Med. Chem. 53 (2010) 3133-3141.

[51] K. Qian, S.L. Morris-Natschke, K.H. Lee, Med. Res. Rev. 29 (2009) 369-393.

[52] K. Qian, K. Nakagawa-Goto, D. Yu, S.L. Morris-Natschke, T.J. Nitz, N. Kilgore, G.P. Allaway, K.H. Lee, Bioorg. Med. Chem. Lett. 17 (2007) 6553-6557.

[53] W. Lu, K. Salzwedel, D. Wang, S. Chakravarty, E.O. Freed, C.T. Wild, F. Li, Antimicrob. Agents Chemother. 55 (2011) 3324-3329.

[54] G. Yebra, A. Holguin, Antivir. Ther. 13 (2008) 1083-1085.

[55] D.J. Knapp, P.R. Harrigan, A.F. Poon, Z.L. Brumme, M. Brockman, P.K. Cheung, J. Clin. Microbiol. 49 (2011) 201-208.

[56] E. Seclen, M. Gonzalez Mdel, A. Corral, C. de Mendoza, V. Soriano, E. Poveda, Aids 24 (2010) 467-469.

[57] N.A. Margot, C.S. Gibbs, M.D. Miller, Antimicrob. Agents Chemother. 54 (2010) 2345-2353.

[58] C.S. Adamson, M. Sakalian, K. Salzwedel, E.O. Freed, Retrovirology 7 (2010) 36.

[59] A.T. Nguyen, C.L. Feasley, K.W. Jackson, T.J. Nitz, K. Salzwedel, G.M. Air, M. Sakalian, Retrovirology 8 (2011) 101.

[60] S.A. Smith, N. Murali, J. Magn. Reson. 136 (1999) 27-36.

[61] A.J. Shaka, J. Keeler, R. Freeman, J. Magn. Reson. 53 (1983) 313-340.

[62] A.J. Shaka, P.B. Barker, R. Freeman, J. Magn. Reson. 64 (1985) 547-552. 